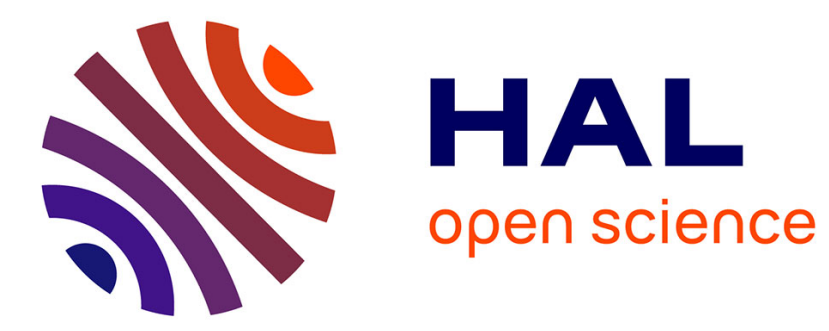

\title{
Composition of hybrid larch (Larix x eurolepis Henry) forest reproductive materials: How much does hybrid percentage affect stand performance?
}

\author{
Gwenaël Philippe, C. Buret, S. Matz, Luc E. Pâques
}

\section{To cite this version:}

Gwenaël Philippe, C. Buret, S. Matz, Luc E. Pâques. Composition of hybrid larch (Larix x eurolepis Henry) forest reproductive materials: How much does hybrid percentage affect stand performance? New Forests, 2016, 47 (4), pp.541-564. 10.1007/s11056-016-9530-z . hal-02499859

\section{HAL Id: hal-02499859 \\ https://hal.science/hal-02499859}

Submitted on 5 Mar 2020

HAL is a multi-disciplinary open access archive for the deposit and dissemination of scientific research documents, whether they are published or not. The documents may come from teaching and research institutions in France or abroad, or from public or private research centers.
L'archive ouverte pluridisciplinaire HAL, est destinée au dépôt et à la diffusion de documents scientifiques de niveau recherche, publiés ou non, émanant des établissements d'enseignement et de recherche français ou étrangers, des laboratoires publics ou privés. 


\section{Composition of hybrid larch (Larix $x$ eurolepis Henry) Forest}

2 Reproductive Materials: how much does hybrid percentage affect

3 stand performance?

4 Gwenaël Philippe, Corinne Buret, Stéphane Matz, Luc E. Pâques

7 G. Philippe . S. Matz

8 Irstea, UR EFNO Ecosystèmes Forestiers, centre de Nogent-sur-Vernisson, Domaine des

9 Barres, F-45290 Nogent-sur-Vernisson, France

11 L.E. Pâques . C. Buret

12 INRA, Centre d'Orléans, Unité d'Amélioration Génétique et Physiologie des Arbres

13 Forestiers, F-45160 Ardon, France

14 e-mail: luc.paques@orleans.inra.fr

15

16 Corresponding author: G. Philippe

17 e-mail address: gwenael.philippe@irstea.fr

18 Phone number: +330238950350

19 Fax number: +33 0238950359 

Materials.

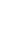

\section{ABSTRACT}

The performance of hybrid larch (Larix x eurolepis) stands may be altered by the fact that the seed lots produced in hybridization seed orchards always contain a proportion of non-hybrid seeds. We studied the effect of such hybrid/non-hybrid mixtures on the productivity and quality of young plantations, through a three-step process: determination of tree species identity with cytoplasmic DNA markers, comparison of hybrid and non-hybrid tree performance, and finally, assessment of thinning impact on hybrid percentage. Overall, we analyzed progenies from eight commercial seed orchards at three sites.

Huge variations in hybrid percentage were found among orchard progenies. Globally, the results concerning survival, susceptibility to drought and to Meria laricis, growth, stem form and wood stiffness were clearly in favor of hybrids. In particular, they grew faster than the non-hybrid trees and exhibited a more homogeneous growth than the mixed progenies. Hybrid superiority was highest for orchards composed of a single maternal clone of a species which was poorly adapted to the planting site. Hybrid percentage was enhanced by successive thinnings. However, a serious loss of income is expected when planting progenies characterized by low initial hybrid percentage and high hybrid superiority. Moreover, variations in hybrid percentage proved to be problematic in seed orchard testing as seed orchard ranking may change depending on whether it is based on the performance of all trees or hybrids only. These variations reduce the reliability of the recommendations typically made to forest owners. For commercial and silvicultural reasons, we suggest setting a minimal threshold level of $60-70 \%$ for hybrid percentage in marketed Forest Reproductive 

doi: 10.1007/s11056-016-9530-z

1 Key-words: hybrid larch, hybrid percentage, Forest Reproductive Material, seed orchard,

2 thinning, growth 


\section{INTRODUCTION}

2 Since their discovery in the Dunkeld estate in the early 1900's (Henry and Flood 1919;

3 Edwards 1956), interspecific hybrids between European larch (EL) (Larix decidua Mill.) and

4 Japanese larch (JL) (Larix kaempferi (Lamb) Carr.) have generated considerable enthusiasm

5 among foresters and, later on, tree breeders. Not only does hybrid larch (Larix $x$ eurolepis

6 Henry) feature good resistance to larch canker (Lachnellula willkommii) (Edwards 1956;

7 Sylvestre et al. 1999), it has shown better growth than either parent species in many instances

8 (e.g. Ferrand and Bastien 1985; Pâques 1992; Baltunis et al. 1998; Pâques et al. 2013) and

9 sometimes has a better form (Lacaze and Birot 1974) and a better survival rate (Miller and

10 Thulin 1967; Zaczek et al. 1994). For wood properties, the hybrid is usually intermediate

11 between EL and JL or better than the best parent (Nanson and Sacré 1978; Reck 1980;

12 Bastien and Keller 1980).

14 Interspecific hybridization breeding programs between European and Japanese larches have been developed since the forties and plantations dedicated to hybrid seed production, named hybridization seed orchards, have been established. About forty first-generation orchards, covering more than 100 ha, have been planted in eleven European countries (Pâques et al. 2013). These orchards differ in the number of genotypes used as male and female (from one to several dozens), the species from which the cones are collected (EL or JL, and sometimes both) and the planting design. EL and JL clones may be intimately mixed, arranged in 21 alternating rows or even planted in separate units especially managed for pollen or seed 22 production (Nanson 2004). The seeds are produced by open-pollination or exceptionally by supplemental mass pollination (SMP) (Philippe and Baldet 1997). 
1 Planting EL and JL genotypes in mixtures allows interspecific crossings to occur and does

2 result in some hybrid seed production as long as their flowering periods are not too much

3 asynchronous (Pâques et al. 2013). However, the proximity of individuals of the same species

4 within the orchard also makes intraspecific crossings possible: among ramets of different

5 clones, among ramets of the same clone or within the same tree. As a consequence, the seed

6 lots produced in hybridization orchards are always somehow composed of a mixture of hybrid

7 seeds and of seeds from one or both parent species (Pâques et al. 2006). The risk of obtaining non-hybrid seeds is a priori limited in orchards including a single maternal clone where intraspecific crossings are limited to selfing if the orchard is well-isolated from incoming pollen. As self-pollinated ovules often produce empty seeds due to embryo abortion (Kosinski 1986; Owens 1995; Slobodnik and Guttenberger 2005; Williams 2007) or seedlings with a

12 low vigor (Dieckert 1964, Nanson 2004), this design is considered optimal for the production of high percentages of hybrid seeds.

The proportion of hybrid seeds also varies according to 1) the respective contributions of the parent species to the pollen cloud (Lewandowski et al. 1994), 2) the extent of the flowering overlap among genotypes of the two species (Nanson 2004, Pâques et al. 2013), and 3) pollination success (Hall and Brown 1977). Those processes involve genetic factors such as clonal flowering ability, phenology and 'selfing ability'; climatic factors at flower initiation, in winter and during pollination (Owens and Blake 1985; Philippe et al. 2006); and in some 21 cases, anthropic factors (effectiveness of flower stimulation treatments and SMP). Therefore, hybrid percentage in commercial seed lots fluctuates from one orchard to another but also, for 
1 For a long time, hybrid percentage could not be quantified because morphological

2 identification of hybrids, EL and JL is impossible for seeds, difficult for young seedlings

3 (Pâques et al. 2006) and very uncertain for saplings. Isozyme markers developed in the 1990's

4 were a considerable improvement (e.g. Häcker and Bergmann 1991) but they were not

5 adapted to all kinds of orchards. Isozymes have now been replaced by molecular markers

6 based on mitochondrial (maternally inherited) and chloroplastic (paternally inherited) DNA

7 that allow reliable taxonomic identification of any seed or seedling (Acheré et al. 2004). The

8 numerous analyses performed from then on with markers show tremendous fluctuations in

9 hybrid percentage among orchard progenies, ranging from less than $10 \%$ to more than $90 \%$

10 (Pâques et al. 2006).

12 In the European Union, seed lots may be marketed with any hybrid percentage provided that it

13 is specified in the official document produced by the seed dealer (Council Directive 14 1999/105/CE, 2000). However, some Member States have imposed additional, more stringent requirements. For example, in France, state grants for planting are contingent upon the use of 16 forest reproductive materials (FRM) with a hybrid percentage higher than $60 \%$.

Besides the problem of genetic conformity of the marketed FRM with the certified seed orchard, producing seed lots with low and variable hybrid percentages may have adverse consequences for foresters: reduced or unstable stand performance, heterogeneous final 21 products and increased susceptibility to specific diseases (e.g. larch canker (Lachnellulla willkommii) and Meria laricis on EL; Phytophtora ramorum on JL). Therefore, it is important to understand the effect of hybrid percentage on stand productivity and quality. In our study, we attempted to answer the following questions: 
1 1) How severely does the mixture of hybrid and non-hybrid seeds in FRM affect stand

2 performance?

3 2) How does thinning impact hybrid percentage over time?

5 Furthermore, in the context of seed orchard testing that is required for certification and

6 deployment recommendations, it is justified to investigate to what extent the ranking obtained

7 in genetic tests varies according to hybrid percentage. Hence, we compared the seed orchard

8 performance considering all trees (mixed progenies) or hybrids alone, both before and after

9 the start of inter-tree competition.

MATERIALS AND METHODS

12

14

\section{Seed orchard composition}

Our study included commercial seed lots collected from eight seed orchards with diverse designs. Their description and codes are provided in Table 1. The orchards were composed of one or several clones of the mother species (either European larch (FH, E, V, FP, S), Japanese $\operatorname{larch}(\mathrm{M}, \mathrm{NT})$ or both $(\mathrm{H}))$ and one or several clones of the paternal species.

\section{Trials}

Our study was based on three trials originally established to compare seed orchard progenies.

The three trials were planted at mid-elevation sites, between $600 \mathrm{~m}$ and $1000 \mathrm{~m}$, with favorable climatic conditions for larch (Table 2). The Peyrat and La Courtine trial sites are subjected to an oceanic climate, more favorable to JL, while the Brenod site, which is more 
1 continental, is more suited to EL. La Courtine and Brenod are twin trials in the sense that they

2 were established with the same genetic materials, i.e. with seedlings deriving from the same

3 seed lots, and raised in the same nursery. Both trials were planted in spring 1995 according to

4 a randomized complete block design with four blocks and 64 seedlings per plot. The 2-year-

5 old seedlings were planted at a $2 \mathrm{~m} \times 3 \mathrm{~m}$ spacing (1,667 individuals per hectare). The third

6 trial at Peyrat was established in spring 2002. Owing to limited planting stock, each genetic

7 unit was planted in a single plot containing 71 to 153 seedlings ( $3 \mathrm{~m} \times 3 \mathrm{~m}$ spacing). A first

8 thinning was carried out at La Courtine and Brenod, in 2005 and 2008, respectively, but not at

9 Peyrat.

\section{Taxonomic identification}

12 In the three trials, the genetic status of individual trees was determined at the seedling/sapling stage with cytoplasmic DNA markers. The combination of information from chloroplastic DNA, inherited from the male parent in the Pinaceae (Owens 1995), and mitochondrial DNA, transmitted by the female parent, enabled us to determine the species of the male and female

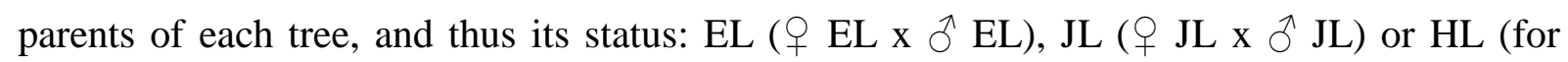

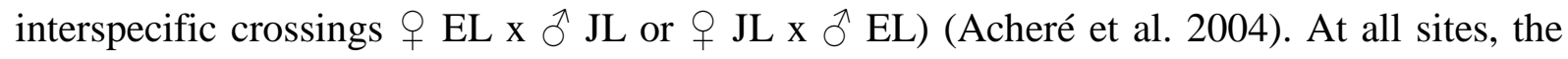
analyses were carried out on buds. At Peyrat, the buds were collected from all seedlings before planting (Table 2). After determination, each seedling was carefully labelled in order to keep track of its identity in plantation. At the other two sites, the buds were collected a few months before thinning (Table 2). At that time, overall survival averaged $96 \%$ at La Courtine and $87 \%$ at Brenod. Taxonomic identification was carried out for all the orchard progenies tested at Brenod but only for four progenies at La Courtine (H83, FH, E, M) to limit costs. In both trials, DNA analyses were restricted to trees from two blocks out of four. 
1 Prior to seed sowing, taxonomic identification had been carried out for each seed lot used in

2 the Peyrat trial. That enabled us to detect a possible difference in hybrid percentage between

3 the seed and seedling stages. The percentages of hybrid and non-hybrid seeds had been

4 determined with the only marker available at that time, i.e. isozyme marker (SKDH; 200

$5 \quad$ seeds per seed lot) as described by Bergmann and Ruetz (1987).

\section{Measurements}

9 The data used in our study were collected at ages 2, 7, 10 and 12 at Peyrat, at ages 6 and 13 at Brenod, and at ages 6 and 10 at La Courtine. The traits recorded at all three sites were related to site adaptation (survival), growth in height and circumference, and stem straightness.

12 Additional traits were assessed at Peyrat: crown dieback following the severe heat wave and drought in summer 2003, needle damage caused by a severe attack of Meria laricis in 2008, and wood quality (modulus of elasticity at age 12).

The impact of the 2003 heat wave was estimated through the presence/absence of damage (10) and its severity (height of top dieback). Needle yellowing or loss caused by M. laricis was recorded using a scoring scale from 1 (severe) to 5 (light) in July 2008. In addition, the subsequent growth reduction was estimated by comparing the length of the terminal shoot in 2008 and from the two previous years. Stem straightness was assessed using a scoring scale

21 from 1 (crooked) to 5 (straight). Total tree volume (V) was estimated from total height $(\mathrm{H})$ and circumference at breast-height (C) according to Pauwels and Rondeux (1999): $23 \mathrm{~V}=0.40678^{-5} * \mathrm{C}^{2} * \mathrm{H}$, with $\mathrm{V}$ in $\mathrm{m}^{3}, \mathrm{C}$ in $\mathrm{cm}$ and $\mathrm{H}$ in $\mathrm{m}$. To estimate modulus of elasticity 24 (MOE), a bending test was carried out on samples of standing trees (18 trees per species and per orchard progeny, on average) with a dedicated device, the Rigidimeter, described by 
1 Launay et al. (2000) and Pâques and Rozenberg (2009). Deviation at $1.3 \mathrm{~m}$ after bending was

2 recorded three times for each of two cardinal directions ( $\mathrm{N}$ and $\mathrm{E}$ ) together with the pressure

3 necessary for bending. MOE (MPa) was estimated as follows:

$4 \quad \mathrm{MOE}=(32 * \mathrm{R} * \mathrm{~F} * \mathrm{a}) /\left(\pi * \mathrm{D}^{4}\right)$ with $\mathrm{R}=$ radius of curvature of the trunk under flexure

$5(\mathrm{~mm})$ that is a function of the length of the measurement bar $(100 \mathrm{~mm})$ and of stem

6 deformation $(\mathrm{mm}), \mathrm{F}=$ force applied to the tree (Newton), $\mathrm{a}=$ distance between the fixation

7 system to the tree and the extremity of the Rigidimeter $(300 \mathrm{~mm})$ and $\mathrm{D}=$ tree diameter $(\mathrm{mm})$.

8 As a result, for a given force and a given stem diameter, MOE is inversely proportional to

9 trunk flexion.

\section{Thinning impact}

13 In order to estimate the effect of thinning on hybrid percentage, we considered both simulated thinnings (at all sites) and actual thinnings (at La Courtine and Brenod). For the simulations made for Peyrat, we fixed the thinning rate at $30 \%$ of the living trees in each plot. Three criteria, measured at age 10, were considered successively: tree volume, stem straightness and an index combining growth and stem straightness. As height had not been measured at age 10, tree volume (V) was estimated on the basis of circumference at breast height (C) (Thill and Palm 1984):

$20 \mathrm{~V}=19.784-3.1514 * \mathrm{C}+0.12589 * \mathrm{C}^{2}-506^{-7} * \mathrm{C}^{3}$ with $\mathrm{V}$ in $\mathrm{dm}^{3}$ and $\mathrm{C}$ in $\mathrm{cm}$

21 The growth-form index, drawn from Magnussen (1990) was calculated as follows:

$22 \mathrm{I}=0.955 * \mathrm{C}+16.096 * \mathrm{SS}$ where $\mathrm{I}$ is the index, $\mathrm{C}$ the circumference expressed in $\mathrm{cm}$ and SS 23 the stem straightness score.

24 For La Courtine and Brenod, the proportion of hybrid to non-hybrid trees was determined 25 after the actual thinnings. They eliminated $42 \%$ and $45 \%$ of the living trees in 2005 and 2008, 
1 respectively; the proportion of planted trees remaining after thinning were $56 \%$ and $47 \%$, or

2940 and 790 stems per ha. In both trials, thinning was partly systematic (elimination of one

3 row per plot to facilitate further management) and partly selective (one third of the trees in the

4 other rows were felled on the basis of vigor, stem form and spatial distribution of the retained

5 trees). In addition, simulations were made using a thinning rate of 50\% (of the living trees)

6 and considering two criteria successively: circumference and stem straightness. We used data

7 collected just before actual thinnings, at ages 10 and 13 for La Courtine and Brenod,

8 respectively. We then simulated second and third thinnings according to the same procedure,

9 considering that tree density would be reduced to 600 and 400 stems per hectare, respectively.

10 The traits taken into account were circumference and stem straightness at age 16 for La

11 Courtine and age 17 for Brenod. For these simulations, we hypothesized that tree ranking

12 would remain unchanged between data collection and the second and third thinnings which are approximately done at ages 18 and 25 , respectively.

\section{Data analysis}

For quantitative traits, we compared the performance of hybrid and non-hybrid trees within each orchard progeny using analyses of variance performed on individual data as follows: $X_{i j k}=\mu+s_{i}+b_{j}+s b_{i j}+\varepsilon_{i j k}$ where $\mu$ is the overall mean, $s_{i}$ is the fixed effect of species $i, b_{j}$ is the fixed effect of block $\mathrm{j}, \mathrm{sb}_{\mathrm{ij}}$ is the interaction effect between species and block, and $\varepsilon_{\mathrm{ijk}}$ is

21 the random error. Species means were compared using Bonferroni test. At Peyrat where the orchard progenies were not repeated in blocks, the model was restricted to: $X_{i j}=\mu+s_{i}+\varepsilon_{i j}$. For proportions, the data were analyzed with Chi-square tests. 
1 The effect of hybrid percentage on the ranking of seed orchard progenies was studied at

2 Brenod and La Courtine. We compared progeny performance by analyses of variance

3 considering either all trees or hybrid trees only. The following model was used:

$4 \quad \mathrm{X}_{\mathrm{ijk}}=\mu+\mathrm{p}_{\mathrm{i}}+\mathrm{b}_{\mathrm{j}}+\mathrm{pb}_{\mathrm{ij}}+\varepsilon_{\mathrm{ijk}}$ where $\mu$ is the overall mean, $\mathrm{p}_{\mathrm{i}}$ is the fixed effect of orchard 5 progeny $i, b_{j}$ is the fixed effect of block $\mathrm{j}, \mathrm{pb}_{\mathrm{ij}}$ is the interaction effect between progeny and 6 block and $\varepsilon_{\mathrm{ijk}}$ is the random error. We used Tukey or Bonferroni tests to compare progeny 7 means, depending on whether the number of data differed or not.

RESULTS

\section{Hybrid percentage in the seed orchard progenies}

Hybrid proportion varied considerably in the studied seed orchard progenies, from $12 \%$ to percentage was higher at the seedling stage than at the seed lot level for most of the progenies tested in the Peyrat trial. The difference was particularly large for $\mathrm{FH}$ and $\mathrm{V}$ whose seeds were collected from a single clone.

\section{Comparison of hybrid and non-hybrid tree performance}

Site adaptation

24 Ten years after planting, overall survival was good at Peyrat (92.9\% on average) with few

25 differences among species $(92.5 \%, 91.5 \%$ and $94.1 \%$ for EL, JL and HL, respectively). 
1 Mortality occurred mainly in the first two years following planting. Significant differences in

2 mortality rates were found for FH and H98 where HL performed better than EL and JL, respectively (Table 3). At Brenod and La Courtine, hybrid and non-hybrid trees did not differ

4 in terms of survival or damage since the trials encountered no health problems after DNA 5 analyses.

7 The heat wave and drought of summer 2003 resulted in shoot diebacks and twig drying in $8 \quad 14.4 \%$ of the seedlings planted at Peyrat. Within the six seed orchard progenies, HL 9 performed at least as well as the parent species (Table 3). Considering both the percentage of damaged trees and the height of top-dieback, the hybrids were or tended to be superior to JL in $\mathrm{H} 87$ and H98. A similar trend was found in most of the progenies when HL and EL were compared but the differences were not significant.

In July 2008, $74 \%$ of the trees at Peyrat were damaged by Meria laricis. Severe foliage discoloration or loss (scores 1 to 3 ) was observed for $90.3 \%$ and $77.3 \%$ of the EL and HL trees, respectively, while only $42.6 \%$ the JL trees were severely affected (Table 3 ). The lesser susceptibility of JL was obvious in the two orchards where JL was the maternal species. The hybrids ranked between the parent species but were closer to EL for needle damage intensity. However, the impact of M. laricis on growth in 2008 proved to be significantly smaller in HL than in EL for V, H87 and H98 (9.4\% loss versus $22.3 \%$ on average, see Table 3); impact on 21 growth was not significantly different from JL for H87 and NT (Table 3). 
1 In all three sites and for almost all the orchard progenies, the hybrids grew faster than EL

2 and/or JL (Table 4). On average, hybrid tree volume was higher by 140\%, though large

3 differences occurred depending on site and orchard progeny. In the two sites favorable to JL,

4 hybrid superiority was very high compared to EL, but only moderate and even sometimes

5 non-significant relative to JL. This was particularly obvious for H87 and H98 at Peyrat. At

6 Brenod, where the continental climate is more suitable to EL, the superiority of HL over JL

7 was more pronounced than at the two oceanic sites, as shown by the results obtained for M 8 and $\mathrm{H} 83$.

9

Whatever the site and the orchard progeny, hybrid superiority over EL was greater for radial 11 growth than for height growth. As a result, the height:diameter ratio was lower for the hybrids

12 (Table 4). No clear trend was found when the hybrids were compared to JL. The hybrids also tended to be less straight than EL but the differences were rarely significant. In addition, the correlations between stem straightness and volume at age 6 were negative but generally weak and non-significant, both in hybrid and non-hybrid trees (data not shown).

Hybrid modulus of elasticity tended to be or was significantly lower than that of EL. The reverse trend was observed when HL was compared to JL (Table 4).

\section{Homogeneity of hybrids relative to mixed seed orchard progenies}

Compared to overall orchard progenies, composed of a mixture of hybrid and non-hybrid trees, the hybrids alone were generally more homogeneous (lower coefficients of variation) 
1 progenies, the differences were higher under oceanic climatic conditions, less adapted to EL

2 (Peyrat and La Courtine). Symmetrically, for progeny M, derived from a single JL maternal

3 clone, the hybrid population was less variable than the mixed progeny in the continental site

4 at Brenod, but not at La Courtine. Regarding the hybrids produced in seed orchards composed

5 of several mother clones, a wide variety of situations was found, even for the different seed

6 lots produced in seed orchard $\mathrm{H}$.

7 or less stable.

\section{First thinning}

The coefficients of variation of the hybrids were most often similar or lower for H:D and similar for stem straightness. For those two traits, the data showed no clear relationship between homogeneity and seed orchard design.

\section{Effect of thinning on hybrid percentage}

At the three sites and for almost all the orchard progenies, simulated thinnings based on growth criteria eliminated a greater proportion of EL and JL trees compared to the hybrids. Consequently, they led to increased hybrid percentages (Fig. 1, 2). Hybrid proportion reached nearly $100 \%$ in the progenies characterized by a high initial hybrid percentage and a great superiority of hybrids over parent species (V, E and FH). In most of the other cases, hybrid percentage increased but remained low or moderate. NT, whose hybrids performed badly relative to JL, was the only case where thinning resulted in a decrease in hybrid percentage. When stem straightness was used as the thinning criterion, hybrid percentages remained more

(1)


1 Simulated thinnings based on the index combining growth and stem form resulted in

2 increased hybrid percentages at Peyrat (Fig. 1). The increases were generally intermediate

3 between those obtained with growth and stem straightness separately. At Brenod and La

4 Courtine, actual thinnings also produced intermediate increases in hybrid percentage,

5 although it should be kept in mind that the thinnings were partly systematic and took into

6 account the distribution of the remaining trees in the field (Fig. 2).

7

\section{Simulation of second and third thinnings at Brenod and La Courtine}

The simulations showed the same patterns as for the first thinning. Selecting the trees for growth resulted in increased hybrid percentages except, of course, for the progenies that already contained nearly $100 \%$ hybrids (Fig. 3). The increase was small for $\mathrm{H}$ progenies in both sites and moderate for M progeny at La Courtine, which is favorable to its maternal JL species. Even after three thinnings, hybrid percentages remained low or moderate $(<60 \%)$ for these orchard progenies. On the contrary, large increases were observed for M and FP at Brenod. After the third thinning, hybrid percentage reached $90 \%$ for M, though it remained far below 100\% for FP (63\%). A thinning selection based on stem form had only limited effects on hybrid percentages, except for FP for which it increased slightly.

\section{Impact of hybrid percentage in seed orchard testing}

Seed orchard progenies were compared in two genetic trials using the data collected at age 6 either from all the trees or from the hybrids alone. At La Courtine, few changes were observed in the ranking for tree volume (Fig. 4), circumference and stem straightness (data not shown). The main difference concerned H83 whose performance was poorly estimated 
1 because of the small number of hybrid trees. On the contrary, the hierarchy was far less stable

2 at Brenod (Fig. 4). Analyzing hybrids alone, instead of mixed progenies, led to a dramatic

3 increase in circumference for FP. Though the mixed FP progeny had a very poor growth, its

4 hybrids did not differ significantly from any other hybrids.

6 Between ages 6 and 13, when the trees in the plots began competing with each other, a change

7 in the ranking of orchard progenies appeared for circumference at Brenod, The gap between

8 the pair FP-M and the three leading progenies (FH, V, E) was appreciably reduced during that

9 period (Fig. 5). The dynamics was particularly clear for the hybrids: girth increment was

10 significantly larger for FP and $\mathrm{M}$ than for $\mathrm{FH}, \mathrm{V}$ and $\mathrm{E}$.

\section{DISCUSSION}

\section{Hybrid percentage in the seed orchard progenies}

We found a wide spectrum of hybrid percentages, from $12 \%$ to $96 \%$, in the seed orchard progenies studied. Considering the genetic and physiological mechanisms against selfpollination that result in embryo abortion and finally in empty or unviable seeds (Dieckert 1964; Kosinski 1986; Slobodnik and Guttenberger 2005; Philippe et al. 2006), we expected hybrid percentage to be high in the progenies from orchards composed of a single mother

21 clone, and lower in the progenies from orchards with several maternal clones. The limited 22 data available in the literature generally concurs (Bergmann and Ruetz 1987; Häcker and Bergmann 1991; Ennos and Tang Qian 1994). 
1 Our results were partly consistent with the above assumption since we found the highest

2 hybrid percentages in the progenies collected from a single clone $(\mathrm{FH}, \mathrm{V}, \mathrm{E})$, and low or

3 moderate hybrid percentages in the two orchards with several maternal clones (H and NT)

4 (Table 1). However, low hybrid percentages were also obtained for three seed orchards

5 composed of a single mother clone (S, FP and, to a lesser degree, M). For those, the non-

6 hybrid trees could have resulted from self-pollination or pollen contamination, not to mention

7 other possible problems due to rejected grafts or mislabeling at various stages of the tree

8 breeding process. None of these explanations could be tested because the markers we used do

9 not make it possible to distinguish between the two kinds of materials, and the isolation of the

10 studied orchards from background pollen was largely unknown.

12 Considering the poor full seed yields resulting from controlled self-pollinations (Kosinski 1986; Slobodnik and Guttenberger 2005), it seemed unlikely at first sight that the high percentages of non-hybrid trees found in several orchard progenies (S, FP, M and FH) derived from selfing. However, Bergmann and Ruetz (1987) mentioned a very low percentage of hybrid seeds (19\%) in the first crop of a young bi-clonal orchard. The fact that this orchard was well-isolated from background pollen leads us to think that selfing was responsible for a large part of the $81 \%$ non-hybrid seeds. Myking and Skroppa (2006) also reported that a seedling lot derived from a seed orchard composed of one single mother clone contained $90 \%$ selfed seeds. Therefore, selfed seeds can represent a larger proportion of the seed lot than 21 initially thought. 
1 In many studies, interspecific hybrids have been compared to the parent species for various

2 traits, particularly growth, in order to estimate hybrid superiority and, thus, to judge the

3 interest of hybrid larch as an afforestation species (e.g. Pâques et al. 2013). Our purpose was

4 quite different. Indeed, comparing hybrids with EL and JL populations composed of mixtures,

5 in unknown proportions, of selfed trees and trees derived from non-related parents would be

6 meaningless in that case. Actually, our study aimed to judge the impact of hybrid percentage

7 on FRM worth and to detect possible differences according to seed orchard design. This

8 implies that we know the respective performance of the populations identified as hybrids or

9 not in the studied orchard progenies.

At Peyrat, few differences were found between hybrid and non-hybrid trees for survival after planting, except for FH and H98. For those progenies, the hybrids survived better than either EL or JL. Mortality mainly occurred in the first two years and can be attributed to the transplanting shock as well as to the heat wave and drought that happened one year after planting. Similar results have been obtained for FH in a sister experiment where the hybrids survived much better than EL seedlings at age 8 ( $86 \%$ versus $38 \%$, data unpublished). Thus, hybrid percentage increased continuously from the seed lot to the nursery and then in the field. This is consistent with the fact that selfed seeds do not germinate well and that the resulting seedlings are generally weak (Dieckert 1964). At Brenod and La Courtine, mortality was extremely limited in all orchard progenies after age 9 and 13, respectively, when tree

21 identity was determined. Therefore, there was no direct evidence that the hybrids survived better than the EL or JL trees. However, although both trials were planted with the same materials, the proportion of hybrids among the orchard progenies in common appeared to be slightly higher at Brenod than at La Courtine (61.2\% and 56.0\%, respectively). At Brenod, 
$14.1 \%$ at La Courtine. This suggests that early mortality was less pronounced in the hybrids

2 than in the non-hybrid trees at Brenod.

4 In addition to mortality, heat and drought caused crown dieback during the second growth

5 season at Peyrat. On the whole, JL was the most damaged, this species being less drought-

6 resistant than EL (Pâques et al. 2013). The hybrids had less frequent and/or less severe

7 dieback than JL. Compared to EL, the hybrids resisted that extreme climatic event as well or even better though the differences were small.

9

A mild, wet spring and a rainy summer favored the development of Meria laricis at Peyrat in 2008. In terms of foliage damage and decrease in growth rate, EL was more severely affected than JL, while the hybrids occupied an intermediate position whatever the orchard progeny. This ranking is consistent with the known susceptibility to needle cast of EL, JL and HL (Batko 1955; Lanier 1976; Ridley and Dick 2001; Pâques et al. 2013).

The hybrids grew faster in height and particularly in diameter in all the orchard progenies studied except NT. For tree volume, the hybrids were superior by $140 \%$ on average at age 6 or 7 , i.e. when inter-tree competition was nil or weak. Still, large variations were found among orchard progenies at each site, and between sites for the progenies tested both at Brenod and La Courtine. These variations seem to be related to orchard design. Firstly, considering $\mathrm{M}$ and $\mathrm{H} 83$, hybrid superiority over JL was much higher at the continental site (Brenod) than at the oceanic site (La Courtine). In addition, the hybrids produced in orchard $\mathrm{H}$ were more superior to EL than to JL at the second oceanic site (Peyrat). Therefore, we are inclined to believe that the difference in growth between hybrid and non-hybrid trees will be 
assumed that the greatest differences in vigor would be found in progenies originating from orchards composed of a single mother clone due to inbreeding depression (Dieckert 1964). This hypothesis was supported by the results we obtained at Brenod, but only partly so by the results from Peyrat and La Courtine. Knowing the pedigree of the non-hybrid seedlings would have helped us interpret the data, but the proportion of trees deriving from self-pollination and pollen contamination could not be determined with the markers we used. Though this theory must be confirmed with a larger and better balanced set of orchard progenies, we consider it more than likely. Finally, we expect hybrid superiority over non-hybrid trees to be maximal in orchards composed of one maternal clone belonging to a species which is poorly adapted to the planting site.

Remarks can be made for two orchards for which information is available. Regarding NT progeny, the small difference in growth between the hybrid and non-hybrid trees might be explained by the inaccurate identity of some mother clones. Indeed, previous DNA analyses showed that some were hybrids and not JL as expected (Pâques, pers. comm.). Therefore, NT progeny was potentially complex, including F1 hybrids and JL trees but also back-crossed trees and F2 hybrids. Regarding V progeny, the large superiority of hybrids over non-hybrids at Peyrat and Brenod, as well as the large increase in hybrid percentage between the seed and seedling stages, lead us to think that most of the non-hybrid individuals derived from selfing. Therefore, the other 12 EL clones planted on the periphery of the seed orchard (van't Leven 1979) probably contributed little to the seed lot. That is consistent with the fact that seed orchard grafts are mainly pollinated by close neighbors (e.g. Philippe et al. 2006).

The hybrids were less slender than EL, a favorable point for wind stability, and similar to JL for that trait. Regarding stem straightness, the differences were small and rarely significant. 
1 The hybrids were no straighter than the parent species, contrary to what Lacaze and Birot 2 (1974) observed.

4 Modulus of elasticity (MOE) is one of the most important mechanical properties of wood.

5 Though faster growing, the hybrids did not differ significantly from the non-hybrids in MOE 6 except for three orchard progenies where it was either inferior to EL (FH and V) or superior to 7 JL (NT).

9 If forest owners want straight and fast-growing materials which are well-adapted to the 10 planting site, they are also interested in homogeneous stands which produce more 11 homogeneous final wood products and make thinning easier and more efficient. Our results 12 show that in most of the orchard progenies the hybrid populations were more homogeneous than the mixed populations in terms of growth traits. This was particularly true when the hybrids derived from a single clone belonging to a species poorly adapted to the planting site. In terms of stem form, no clear trend toward homogeneity was found, though the hybrids were rarely more variable than the mixed progenies.

The thinning simulations carried out for the three sites showed that the plots became richer in hybrids when trees were selected for vigor. Logically, hybrid percentage enhancement depended on three factors: 1) the percentage of trees eliminated in each orchard progeny, 2) the superiority of hybrids over EL and/or JL trees, and 3) the hybrid percentage before thinning. In the simulated thinnings for Brenod, the changes in hybrid percentage for FP and, to a lesser extent, for $\mathrm{M}$ were explained by the last factor. Despite the clear superiority of the 
1 hybrids, the increase in hybrid percentage remained limited because of the small number of

2 available hybrids. For FP, for example, even though all the hybrids were retained, they still

3 represented only $42 \%$ of the population after the first thinning. When the trees were selected

4 for stem straightness, hybrid percentage did not vary much. As growth and stem straightness

5 were weakly correlated, a selective thinning based on both traits was expected to result in an

6 intermediate enrichment in hybrids. That is precisely what was obtained in the simulations

7 carried out on the basis of the vigor-form index at Peyrat, and in the field at Brenod and La

8 Courtine. However, the effect of actual thinning could not be tested at Peyrat because the trial

9 has not been thinned yet.

11 For the Brenod and La Courtine trials, we simulated second and third thinnings reducing 12 densities to 600 and 400 stems per hectare, respectively. We based these simulations on the latest data available and considered that tree ranking would remain unchanged. When trees were selected for vigor, dramatic increases in hybrid percentage occurred for the orchard progenies characterized by both a large superiority of hybrids and a low or moderate hybrid percentage after the first thinning ( $\mathrm{M}$ and FP at Brenod). Nevertheless, FP progenies were only $63 \%$ hybrids even after the third thinning. In the other orchard progenies, hybrid percentages remained either very high $(\mathrm{FH}, \mathrm{V}, \mathrm{E})$, or low $(\mathrm{H})$. As for the first thinning, selecting for stem form did not produce substantial variations in hybrid percentage. A thinning based on growth and form would most likely result in intermediate changes.

\section{Consequences for the forest owner}

24 From a silvicultural point of view, hybrid percentage in Forest Reproductive Material (FRM) 
1 where the seed has been produced. Hybrid percentage does not matter if the production

2 objective is focused on stem straightness. However, it would be nonsense to use expensive

3 hybrid larch seedlings for that sole purpose. On the contrary, hybrid percentage is of major

4 importance when timber production is concerned, though its impact varies according to the

5 seed orchard progeny and the planting site. When hybrids do not differ much from EL and JL

6 trees, the potential loss of productivity should be acceptable, even if hybrid percentage in the

7 planting stock is moderate. In our study, this case corresponds to orchards with several clones

8 from a mother species which is well-adapted to the planting site. Inversely, the risk of poor

9 timber production is the highest for orchard progenies in which the hybrids grow much faster

than the non-hybrid trees. According to our results, this concerns the progenies produced from

11 a single mother clone, especially when it belongs to a species that is poorly adapted to the

12 planting site. Nevertheless, the consequences will probably remain negligible if the hybrid percentage is more than $60-70 \%$, which corresponds to the percentage of trees left after the

14 first thinning in standard silviculture (Pauwels and Rondeux 2000). With such a hybrid percentage, the plantation will be composed of almost $100 \%$ hybrid trees from the second thinning on, i.e. when the forest owner starts to yield profits. Still, a low hybrid percentage means that there are fewer possibilities to compensate for mortality or game, insect, frost damage and also fewer possibilities of choice at the time of thinning. Finally, if the owner's objective is biomass production, the hybrid percentage should be as high as possible.

Furthermore, precautions must be taken for sanitary reasons in afforestation areas favorable to larch canker, i.e. areas with frequent high air humidity. In such sites, the forest owner must be cautious in using FRM produced in seed orchards composed of several maternal clones of EL of alpine origin. Indeed, the non-hybrid seeds or seedlings will be alpine EL and those 
1 Guinot and Delatour 1983; Pâques et al. 2013). Therefore, the hybrid percentage threshold

2 should be set higher, close to $100 \%$, for the above-mentioned orchards in the areas at risk in

3 order to limit canker development and fungus dispersal.

To conclude, we must stress the fact that our study does not allow us to specify the minimal hybrid percentage required for each orchard progeny to ensure good stand production. To do so would require establishing several plots per progeny with increasing hybrid percentages in order to study a gradient of mixture. Such an experiment would be a long and complicated undertaking and, to our knowledge, has not been attempted to date.

\section{Difficulties related to variable hybrid percentages in seed orchard comparison tests}

In old and middle-aged tests, the hybridization orchards compared are generally represented varies considerably among orchards and years, and hybrid superiority differs greatly from one orchard to another. Therefore, it is quite justified to question the accuracy of results based on mixed orchard progeny performance and, thus, the reliability of the recommendations made to forest owners based on such results. To answer this question, we compared the orchard progenies at Brenod and La Courtine, considering either their overall performance (all trees) or hybrid performance (hybrid trees only).

21 The comparison was done at age 6, i.e. before among-tree competition had started. At La 22 Courtine, the orchard progenies ranked similarly for growth and stem form whatever the 23 populations analyzed. However, only two categories of materials were compared: 1) 24 progenies characterized by highly superior hybrids but also a low percentage of non-hybrid trees (FH and E); and 2) progenies whose low hybrid percentage was compensated for by 
1 little difference in growth between the hybrids and the non-hybrids ( $\mathrm{H}$ and $\mathrm{M})$. At Brenod,

2 where the FP progeny was characterized by both a low hybrid percentage and highly superior

3 hybrids, things were quite different. Considering hybrids alone, FP did not differ significantly

4 from the other orchard progenies for radial growth. This indicates that the poor growth FP has

5 shown in France and other European countries (Philippe et al. 2002) was not due to an

6 intrinsic characteristic of the seed orchard but rather to the low percentage of hybrids in the

$7 \quad$ seed lot used in the trials.

8 The above example raises an essential question: should hybrid FRM recommendations take

9 into account the overall or the hybrid performance? Both approaches have disadvantages. A

10 given seed lot may be atypical and it would be risky to base a general judgment on its

11 performance. On the other hand, hybrid performance might never be attained for some

12 orchards. That is precisely the case for the Halle orchard whose progenies have consistently

13 low or moderate hybrid percentages. In addition, as it will be discussed below, a judgement

14 founded on hybrid performance may be biased because of competition effects. To be reliable,

15 recommendations should be based on the performance of seed lots as similar as possible to

16 those available on the market. For that, we would need to know the annual variability in

17 hybrid percentage for the different seed lots produced in each orchard, or to market only

18 Forest Reproductive Materials with a high hybrid percentage in order to reduce the gap

19 between overall and hybrid performance. Another alternative would consist in testing seed lot

20 mixtures instead of single seed lots in order to estimate their "average performance".

22 Furthermore, interpreting data collected in seed orchard comparison tests may be tricky when 23 the trees get older and are competing with each other. Indeed, competition intensity, which 24 strongly influences tree growth, may vary with the orchard progeny or, more precisely, with 25 progeny homogeneity. In our study for example, the V, E and FH hybrids that are surrounded 
1 by other hybrids of about the same size are at a disadvantage compared with the few FP

2 hybrids that dominate neighboring selfed trees and are consequently in a nearly free-growth

3 situation. Puzzling results or even misinterpretations may result from such differences in

4 competition intensity. At Brenod for example, seed orchard ranking was altered between the

5 ages of 6 and 13, i.e. after the onset of competition. The FP hybrids and, to a lesser extent, the

6 M hybrids, showed the highest growth during that period whereas they were relatively weak

7 until age 6. It is not impossible that those hybrids grow slowly when young, and then increase

their growth rate as they age. However, FP and M were both characterized by a low hybrid

percentage and a large superiority of hybrids over EL or JL trees. That leads us to believe that

competition was also involved in the sudden, unexpected change in ranking. If this

assumption is correct, a judgement based on hybrid performance would result in an overestimate of the worth of such seed orchards. Therefore, it seems necessary to take competition into account. Many competition indices have been developed by tree growth modelers to estimate the impact of competition on target tree growth (Biging and Dobbertin 1995). Introducing one of these indices as covariable, for instance the basal area of neighbor trees within a given radius, would help to separate genetic and competition effects.

\section{CONCLUSION}

Our results, based on a representative sample of European hybridization orchards of larch, showed that it is almost always in the interest of forest owners to use hybrid larch Forest Reproductive Materials (FRM) with hybrid percentages that are as high as possible. Indeed, the hybrids in our study had several advantages: 1) they were more vigorous and generally thicker than the non-hybrid trees without degradation in stem straightness; 2) they survived and resisted the 2003-summer heat and drought spell at least as well as the non-hybrids did; 3) 
1 they were less susceptible to Meria laricis than the European larch trees; and 4) they were

2 more homogeneous than the mixed progenies for growth traits. However, the commercial

3 seed lots studied in this paper had highly variable hybrid percentages. Hybrid percentage did

4 actually increase over time owing to better seed viability and/or seedling survival and, more

5 significantly, thinning. Several thinnings are nevertheless necessary to compensate for low

6 initial hybrid percentage in some orchard progenies and this means a serious loss of income

7 for forest owners. According to our results, it seems that the risk is maximal for orchards with

8 a single mother clone from a species which is poorly adapted to the afforestation site. It is

9 therefore essential that forest owners are informed of orchard composition, and more

10 particularly of the number, species and origin of the maternal clones.

12 Seed orchard managers, foresters and policy-makers should question commercializing and 13 planting so-called "hybrid larch" FRMs with low hybrid percentage. It would be reasonable to 14 set a minimal threshold of hybrid percentage for commercialization of at least $60-70 \%$. In this 15 way, commercial disputes and lawsuits such as those reported by Myking and Skroppa (2006) 16 could be avoided. Setting that threshold would also reduce the risk of misinterpretation in 17 seed orchard testing. Different measures can be proposed to help increase FRM hybrid 18 percentage. These measures can be taken at various steps in the production process, from genotype selection to seedling selection in the nursery (Table 6). 


\section{ACKNOWLEDGEMENTS}

2 This study was initiated in the frame of the European project "Towards a European larch

3 wood chain" (FAIR5-CT 98-3354 and CEC-NEI-IC20 CT98-0310) funded by the European

4 Commission. From 2002 on, it received financial support from the French Ministry in charge

5 of forests (Direction générale de la performance économique et environnementale des

6 entreprises - DGPE). We thank the foreign scientists who shared seeds from their seed

7 orchards, the managers of the trials (ONF: French Forest Service) and the technical staff who

8 carried out the field measurements (D. Veisse from INRA-UE GBFOR and ONF-PNRGF at

9 Peyrat-le-Château). We also acknowledge E. Collin and the three anonymous reviewers for

10 their useful comments, as well as Vicki Moore for reviewing the English manuscript.

11

12 Conflict of interest

13 The authors declare that they have no conflict of interest.

14

15 


\section{REFERENCES}

2 Acheré V, Faivre Rampant P, Pâques LE, Prat D (2004) Chloroplast and mitochondrial

3 molecular tests identify European x Japanese larch hybrids. Theor Appl Genet 108:1643-1649

4

5 Baltunis BS, Greenwood MS, Eysteinsson T (1998) Hybrid vigor in Larix: growth of intra6 and interspecific hybrids of Larix decidua, L. laricina and L. kaempferi after 5-years. Silvae

7 Genetica 47, 5-6:288-293

Bastien JC, Keller R (1980) Intérêts comparés du mélèze hybride (Larix x eurolepis Henry) avec les deux espèces parentes. RFF 32 (6):521-530

11

Batko S (1955) Meria laricis on Japanese and hybrid larch in Britain. Trans Brit Mycol Soc $39(1): 13-16$

14

Bergmann F, Ruetz W (1987) Identifizierung von Hybridlärchensaatgut aus Samenplantagen mit Hilfe eines Isoenzym-Markers. Silvae Genet 36, 2:102-105

17

18 Biging GS, Dobbertin M (1995) Evaluation of competition indices in individual tree growth models. For Sci, 41 (2):360-377

21 Colas F, Perron M, Tousignant D, Parent C, Pelletier M, Lemay P (2008) A novel approach 22 for the operational production of hybrid larch seeds under northern climatic conditions. For 
1 Council Directive 1999/105/CE (2000) In: Official Journal of the European Communities,

2 Vol. 43, 15 January 2000, pp. 17-40

3

4 Dieckert H (1964) Einige untersuchungen zur selbststerilität und inzucht bei fichte und lärche.

5 Silvae Genet 13:77-86

6

7 Edwards MV (1956) The hybrid larch. Larix x eurolepis Henry. Forestry 24:29-43

9 Ennos RA, Tang Qian (1994) Monitoring the output of a hybrid larch seed orchard using isozyme markers. Forestry, Vol.67, $\mathrm{N}^{\circ} 1: 63-74$

11

12 Ferrand JC, Bastien JC (1985) Bilan à 26 ans d'une plantation comparative de mélèzes. Revue

Häcker M, Bergmann F (1991) The proportion of hybrids in seed from seed orchard composed of two larch species (L. europaea and L. leptolepis). Ann Sci For 48:631-640

Hall JP, Brown IR (1977) Embryo development and yield of seed in Larix. Silvae Genet 26,

Henry A, Flood MG (1919) History of Dunkeld hybrid larch, Larix eurolepis, with notes on other hybrid conifers. Proc Roy Irish Acad, Sec. B35, N4:55-66 
2 Lacaze JF, Birot Y (1974) Bilan d'une expérience comparative de provenances de mélèzes à

3 l'âge de 13 ans. Ann Sci For, 22 (2):321-351

4

5 Lanier L, Joly P, Bondoux P, Bellemère A (1976) Les maladies du mélèze. In: Mycologie et 6 pathologie forestières, Tome II Pathologie forestière. Masson ed., Paris, $496 \mathrm{p}$

7 and hybrid larch in New Zealand. Research leaflet 17, New Zealand Forest Service. 4 p

Launay J, Rozenberg P, Pâques LE, Dewitte JM (2000) A new experimental device for rapid measurement of the trunk equivalent modulus of elasticity on standing trees. Ann For Sci 57:351-359

Leven van't EM (1979) De zaagaarden van Staatsbosbeher (The seed orchards of the State Forest Service). Rijkinstituut voor onderzoek in de bos-en landschapsbouw "De Dorschkamp", Wageningen, The Netherlands, Mededeling nr. 178, 1-32

Lewandowski E, Nikkanen T, Burczyk J (1994) Production of hybrid seed in a seed orchard of two larch species, Larix sibirica and Larix decidua. Scand J For Res, vol 9, 3:214-217

Magnussen S (1990) Selection index: economic weights for maximum simultaneous genetic gain. Theor Appl Genet 79: 289-293

Miller JT, Thulin IJ (1967) Five-year survival and height compared for European, Japanese 24 
1 Myking T, Skoppa T (2006) Certification of forest reproductive material - is present practice

2 sufficient? IPGRI newsletter for Europe, ${ }^{\circ} 33$, Nov. 2006, p.13

4 Nanson A (2004) Génétique et amélioration des arbres forestiers. Les presses agronomiques 5 de Gembloux, Gembloux

Nanson A, Sacré E (1978) A propos de l'hétérosis de Larix x eurolepis en particulier pour les propriétés du bois. Bull Rech Agron, Gembloux 13 (4):323-336

9

Owens JN (1995) Reproductive biology of larch. In: Ecology and management of Larix

11 forests: a look ahead, proceedings of an international symposium, Whitefish, Montana, USA, oct. 5-9, 1992, Schmidt WC and McDonald KJ (compilers), pp 97-109

Owens JN, Blake MD (1985) Forest tree seed production. Information report PI-X-53,

Pâques LE (1992) Performance of vegetatively propagated Larix decidua, L. kaempferi and L. laricina hybrids. Ann Sci For 49:63-74

Pâques L.E, Rozenberg P (2009) Ranking larch genotypes with the Rigidimeter: relationships

21 between modulus of elasticity of standing trees and of sawn timber. Ann For Sci 66 (4):1-7

23 Pâques LE, Philippe G, Prat D (2006) Identification of European and Japanese larch and their 24 interspecific hybrid with morphological markers: application to young seedlings. Silvae Genet 
2 Pâques LE, Foffova E, Heinze B, Lelu-Walter MA, Liesebach M, Philippe G (2013) Larches

3 (Larix sp.). In: Forest tree breeding in Europe: current state-of-the-art and perspectives, Part I

4 Breeding of conifers, Pâques LE (ed), Springer, pp 13-122

6 Pauwels D, Rondeux J (1999). Tarifs de cubage pour les petits bois de mélèze en Ardenne.

7 Cahiers forestiers de Gembloux, $\mathrm{n}^{\circ} 23,10 \mathrm{p}$

9 Pauwels D, Rondeux J (2000) Le mélèze, une essence à haut potentiel de production. Silva

Belgica, 107, $n^{\circ} 3,6-10$

11

Philippe G, Baldet P (1997) Electrostatic dusting: an efficient technique of pollination in larch. Ann Sci For 54: 301-310

14

Philippe G, Baldet P, Héois B, Ginisty C (2006) Reproduction sexuée des conifères et 16 production de semences en vergers à graines. Quae (ed), $570 \mathrm{p}$

17 (6/7):117-120

Philippe G, Curnel Y, Jacques D, Lee SJ, Matz S (2002) Performances of hybrid larch (Larix $x$ eurolepis Henry) varieties across Europe: early results for survival stem form and growth rate. In: Proceedings meeting IUFRO WP S2.02-07, compiled by Pâques LE, Gap, Auvergne \& Limousin, September 16-21, 2002, pp 127-139

Reck S (1980) Untersuchung über das holz der hybridlärche. Allg. Forst-u.J.-Ztg 151 5 5 
1 Ridley GS, Dick MA (2001) An Introduction to The Diseases of Forest and Amenity Trees in

2 New Zealand. Scion Forest Research Bulletin 220

3

4 Slobodnik B, Guttenberger H (2005) Zygotic embryogenesis and empty seed formation in $5 \quad$ European larch (Larix decidua Mill.). Ann For Sci 62:129-134.

6

7 Sylvestre-Guinot G, Delatour C (1983) Possibilité d'appréciation de la sensibilité du genre $8 \quad$ Larix au Lechnellula willkommii (Hartig) dennis par inoculations artificielles. Ann Sci For 40:

$9 \quad 337-354$

10

11 Sylvestre G, Pâques LE, Delatour C (1999) Résistance du mélèze hybride inoculé par

12 Lachnellula willkommii. Ann Sci For 56: 485-492

13

14 Thill A, Palm R (1984) Etude dendrométrique des mélèzes. Notes du Centre d'Ecologie 15 Forestière et Rurale ${ }^{\circ}$ 47, Gembloux

16

17 Williams CG (2007) Re-thinking the embryo lethal system within the Pinaceae. Can J Bot 85:667-677

19

20 Zaczek JJ, Steiner KC, Shipman RD (1994) Performance of Japanese and hybrid larch 21 progenies in Pennsylvania. North J Appl For 11(2): 53-57. 
1 Table 1 Composition of tested seed orchards and hybrid percentages in the seed lots and

2 orchard progenies studied at Peyrat, Brenod and La Courtine

\begin{tabular}{|c|c|c|c|c|c|c|c|c|}
\hline \multirow{3}{*}{$\begin{array}{l}\text { Seed orchard } \\
\text { (country) }\end{array}$} & \multirow{3}{*}{$\begin{array}{c}\text { Orchard } \\
\text { progeny } \\
\text { code }\end{array}$} & \multirow{3}{*}{$\begin{array}{c}\text { Orchard } \\
\text { composition } \\
(\underline{\text { O }} /)^{\mathrm{a}}\end{array}$} & \multirow{3}{*}{$\begin{array}{l}\text { Crop } \\
\text { year }\end{array}$} & \multirow[t]{3}{*}{ Test site } & \multicolumn{4}{|c|}{ Taxonomic identification $^{c}$} \\
\hline & & & & & \multirow[t]{2}{*}{ Sample size } & \multicolumn{3}{|c|}{ Genetic status (\%) } \\
\hline & & & & & & ELxEL & JLXJL & ELXJL + JLXEL \\
\hline \multirow{4}{*}{$\begin{array}{l}\text { FH } 201 \text { Barres } \\
\text { (France) }\end{array}$} & \multirow{4}{*}{ FH } & \multirow{4}{*}{$\underbrace{1 \mathrm{EL}}_{J L} \times 1 \mathrm{FS}^{\mathrm{d}}$} & \multirow{4}{*}{1992} & Peyrat & 200 seeds & 50.7 & 0 & 49.3 \\
\hline & & & & & 81 seedlings & 28.4 & 0 & \\
\hline & & & & Brenod & 109 trees & 14.7 & 0 & 85.3 \\
\hline & & & & La Courtine & 115 trees & 15.6 & 0 & 84.4 \\
\hline \multirow{2}{*}{$\begin{array}{l}\text { Maglehem } \\
\text { (Sweden) }\end{array}$} & \multirow{2}{*}{ M } & \multirow{2}{*}{$\underline{1 \mathrm{JL}} \times 8 \mathrm{EL}$} & \multirow{2}{*}{1992} & Brenod & 110 trees & 0 & 57.3 & 42.7 \\
\hline & & & & La Courtine & 121 trees & 1.7 & 60.3 & 38.0 \\
\hline \multirow{2}{*}{$\begin{array}{l}\text { Esbeek } \\
\text { (The Netherlands) }\end{array}$} & \multirow{2}{*}{$\mathrm{E}$} & \multirow{2}{*}{$\underline{1 \mathrm{EL}} \times 4 \mathrm{JL}$} & \multirow{2}{*}{1992} & Brenod & 111 trees & 2.7 & 0.9 & 96.4 \\
\hline & & & & La Courtine & 115 trees & 8.7 & 1.7 & 89.6 \\
\hline \multirow{3}{*}{$\begin{array}{l}\text { Vaals }{ }^{\mathrm{e}} \\
\text { (The Netherlands) }\end{array}$} & \multirow{3}{*}{ V } & \multirow{3}{*}{$\underline{1 \mathrm{EL}} \times 26 \mathrm{JL}$} & 1996 & Peyrat & 200 seeds & 32.0 & 0 & 68.0 \\
\hline & & & & & 118 seedlings & 22.3 & 0 & 77.7 \\
\hline & & & 1992 & Brenod & 108 trees & 7.4 & 0 & 92.6 \\
\hline \multirow{7}{*}{ Halle (Belgium) } & H87 & \multirow{4}{*}{$\underline{15 \mathrm{EL}} \times \underline{15 \mathrm{JL}}$} & 1987 & Peyrat & 205 seeds & 30.2 & 34.2 & 35.6 \\
\hline & & & & & 170 seedlings & 26.7 & 32.0 & 41.3 \\
\hline & H98 & & 1998 & Peyrat & 205 seeds & 22.4 & 30.2 & 47.3 \\
\hline & & & & & 160 seedlings & 29.0 & 23.0 & 48.0 \\
\hline & $\mathrm{H} 80$ & \multirow{3}{*}{$\underline{15 \mathrm{JL}} \times 15 \mathrm{EL}$} & 1980 & Brenod & 117 trees & 3.4 & 70.1 & 26.5 \\
\hline & H83 & & 1983 & & 112 trees & 3.6 & 75.9 & 20.5 \\
\hline & $\mathrm{H} 83$ & & 1983 & La Courtine & 124 trees & 0 & 87.9 & 12.1 \\
\hline FP237 (Denmark) & FP & $1 \mathrm{EL} \times 17 \mathrm{JL}$ & 1992 & Brenod & 96 trees & 72.9 & 1.0 & 26.0 \\
\hline \multirow{2}{*}{$\begin{array}{l}\text { Schnappenhammer } \\
\text { (Germany) }\end{array}$} & \multirow[t]{2}{*}{$\mathrm{S}$} & \multirow[t]{2}{*}{$\underline{1 \mathrm{EL}} \times 1 \mathrm{JL}$} & \multirow[t]{2}{*}{1983} & \multirow[t]{2}{*}{ Peyrat } & 200 seeds & 86.4 & 0 & 13.6 \\
\hline & & & & & 131 seedlings & 82.0 & 1.0 & 17.0 \\
\hline \multirow{2}{*}{$\begin{array}{l}\text { Wiston - NT23 } \\
\text { (UK) }\end{array}$} & NT & $33 \mathrm{JL} \times 33 \mathrm{EL}$ & 1996 & Peyrat & 200 seeds & 0 & 77.5 & 22.5 \\
\hline & & & & & 99 seedlings & 0 & 77.6 & 22.4 \\
\hline
\end{tabular}

$4{ }^{\mathrm{a}}$ This column indicates the number of clones of European larch (EL) and Japanese larch (JL) 5 included in the seed orchard; the clone or set of clones used as maternal parent is underlined.

${ }^{\mathrm{b}}$ Crop year denotes the year of seed harvesting

${ }^{\mathrm{c}}$ The genetic status of the living trees was determined before the $1^{\text {st }}$ thinning at La Courtine and Brenod ( 9 and 13 years after planting, respectively) while all the seedlings were analyzed before planting at Peyrat

${ }^{\mathrm{d}}$ FS denotes full-sib family

${ }^{\mathrm{e}}$ Vaals seed orchard includes 13 clones of EL and 26 clones of JL but the cones were collected in the central part of the orchard composed of a single maternal clone (van't Leven 17 1979) 
Table 2 Main characteristics of the Peyrat, Brenod and La Courtine trials: site conditions, trial composition and design, trial management and historical account of the main events (planting, thinning and taxonomic identification)

\begin{tabular}{|c|c|c|c|}
\hline Site & Peyrat-le-Château & Brenod & La Courtine \\
\hline $\begin{array}{l}\text { Location } \\
\text { - longitude } \\
\text { - latitude } \\
\text { - elevation } \\
\text { - type of land }\end{array}$ & $\begin{array}{l}1^{\circ} 44^{\prime} \mathrm{E} \\
45^{\circ} 47^{\prime} \mathrm{N} \\
579 \mathrm{~m} \\
\text { Forest nursery }\end{array}$ & $\begin{array}{l}5^{\circ} 38^{\prime} \mathrm{E} \\
46^{\circ} 06^{\prime} \mathrm{N} \\
995 \mathrm{~m} \\
\text { Agricultural land }\end{array}$ & $\begin{array}{l}2^{\circ} 19^{\prime} \mathrm{E} \\
45^{\circ} 45^{\prime} \mathrm{N} \\
830 \mathrm{~m} \\
\text { Forest }\end{array}$ \\
\hline $\begin{array}{l}\text { Climate }^{\mathrm{a}} \\
- \text { mean annual }^{\mathrm{a}} \\
-\mathrm{T}^{\mathrm{b}} \text { April-Sept. } \\
\text { - annual rainfall } \\
\text { - rainfall April-Sept. }\end{array}$ & $\begin{array}{l}9.7^{\circ} \mathrm{C} \\
13.9^{\circ} \mathrm{C} \\
1196 \mathrm{~mm} \\
542 \mathrm{~mm} \\
\end{array}$ & $\begin{array}{l}6.9^{\circ} \mathrm{C} \\
11.6^{\circ} \mathrm{C} \\
1682 \mathrm{~mm} \\
781 \mathrm{~mm} \\
\end{array}$ & $\begin{array}{l}7.7^{\circ} \mathrm{C} \\
12.0^{\circ} \mathrm{C} \\
1058 \mathrm{~mm} \\
501 \mathrm{~mm} \\
\end{array}$ \\
\hline $\begin{array}{l}\frac{\text { Soil }}{\text { - bedrock }} \\
\text { - soil depth } \\
\text { - texture }\end{array}$ & $\begin{array}{l}\text { Granite } \\
>40 \mathrm{~cm} \\
\text { Sandy }\end{array}$ & $\begin{array}{l}\text { Limestone (cracked } \\
\text { blocks) } \\
20-40 \mathrm{~cm} \\
\text { Surface loam then } \\
\text { clay at depths }\end{array}$ & $\begin{array}{l}\text { Granite } \\
>50 \mathrm{~cm} \\
\text { Loamy clay }\end{array}$ \\
\hline $\begin{array}{l}\text { Genetics } \\
\text { - tested orchards } \\
\text { - orchard progenies (\#) } \\
\text { - trial design }\end{array}$ & $\begin{array}{l}5 \\
6 \\
1 \text { plot per progeny } \\
(71-153 \text { seedlings })\end{array}$ & $\begin{array}{l}6 \\
7 \\
7 \text { progenies x } 4 \text { blocks } \\
\text { x } 64 \text { seedlings per plot } \\
\end{array}$ & $\begin{array}{l}6 \\
7 \\
\text { cf Brenod }\end{array}$ \\
\hline $\begin{array}{l}\text { Trial management } \\
\text { - planting date } \\
\text { - spacing } \\
\text { - type of seedlings } \\
\text { - seedling age at planting } \\
-1 \text { st thinning date } \\
-\% \text { of living trees felled }\end{array}$ & $\begin{array}{l}\text { March } 2002 \\
3 \mathrm{~m} \times 3 \mathrm{~m} \\
\text { Bare roots } \\
3 \text { years } \\
\text { Planned for } 2016\end{array}$ & $\begin{array}{l}\text { April } 1995 \\
3 \mathrm{~m} \times 2 \mathrm{~m} \\
\text { Bare roots } \\
2 \text { years } \\
\text { August } 2008 \\
45 \%\end{array}$ & $\begin{array}{l}\text { April } 1995 \\
3 \mathrm{~m} \times 2 \mathrm{~m} \\
\text { Bare roots } \\
2 \text { years } \\
\text { May } 2005 \\
42 \% \\
\end{array}$ \\
\hline $\begin{array}{l}\text { Taxonomic identification } \\
\text { - studied genetic units }\end{array}$ & All & All (2 blocks) & $\begin{array}{l}\mathrm{FH}, \mathrm{H} 83, \mathrm{E}, \mathrm{M} \\
\text { (2 blocks) }\end{array}$ \\
\hline - bud collection date & Fall 2000 & February 2008 & February 2004 \\
\hline
\end{tabular}

${ }^{a}$ All data were obtained from Météo-France (Aurelhy simulations for the period 1971-2000)

${ }^{\mathrm{b}} \mathrm{T}$ is temperature 
Table 3 Performance of hybrid and non-hybrid trees for adaptive traits for the six orchard progenies studied at Peyrat. The heatwave occurred in summer 2003 and the attack of Meria laricis in summer 2008, i.e. two years and seven years after planting, respectively.

\begin{tabular}{|c|c|c|c|c|c|c|}
\hline \multirow{2}{*}{$\begin{array}{l}\text { Orchard } \\
\text { progeny } \\
\text { code }\end{array}$} & \multirow{2}{*}{$\underset{\mathrm{a}}{\text { Species }}$} & \multirow{2}{*}{$\begin{array}{c}\% \\
\text { mortality } \\
\text { at age } 10 \\
\mathrm{~b}, \mathrm{~d}\end{array}$} & \multicolumn{2}{|c|}{ Shoot dieback after heatwave } & \multicolumn{2}{|c|}{ Meria laricis damage } \\
\hline & & & $\begin{array}{c}\% \text { trees } \\
\text { affected } \\
b, \mathrm{~d}\end{array}$ & $\begin{array}{l}\% \text { of stem length } \\
\text { affected }^{\mathrm{b}, \mathrm{d}}\end{array}$ & $\begin{array}{l}\% \text { trees severely } \\
\text { affected }^{\mathrm{b}, \mathrm{d}}\end{array}$ & $\begin{array}{l}\text { Growth } \\
\text { reduction } \\
(\%)^{\text {b,c,d }}\end{array}$ \\
\hline $\mathrm{FH}$ & $\begin{array}{l}\text { HL } \\
\text { EL }\end{array}$ & $\begin{array}{c}15 \\
55^{* * * *}\end{array}$ & $\begin{array}{c}14 \\
22 \mathrm{NS}\end{array}$ & $\begin{array}{c}19 \\
28 \mathrm{NS}\end{array}$ & $\begin{array}{c}86 \\
100 \mathrm{NS}\end{array}$ & $\begin{array}{c}-7 \\
-16 \mathrm{NS} \\
\end{array}$ \\
\hline V & $\begin{array}{l}\text { HL } \\
\text { EL }\end{array}$ & $\begin{array}{c}2 \\
4 \mathrm{NS}\end{array}$ & $\begin{array}{c}5 \\
14 \mathrm{NS} \\
\end{array}$ & $\begin{array}{c}5 \\
10 \mathrm{NS}\end{array}$ & $\begin{array}{c}80 \\
100^{*}\end{array}$ & $\begin{array}{c}-3 \\
-26^{* *}\end{array}$ \\
\hline H87 & $\begin{array}{l}\mathrm{HL} \\
\mathrm{EL} \\
\mathrm{JL}\end{array}$ & $\begin{array}{c}4 \\
9 \mathrm{NS} \\
2 \mathrm{NS} \\
\end{array}$ & $\begin{array}{c} \\
6 \mathrm{NS} \\
13 \mathrm{NS} \\
\end{array}$ & $\begin{array}{c}4 \\
28 \mathrm{NS} \\
10 \mathrm{NS} \\
\end{array}$ & $\begin{array}{c}85 \\
100 * \\
42 * * * \\
\end{array}$ & $\begin{array}{c}-11 \\
-29 * * \\
0 \mathrm{NS} \\
\end{array}$ \\
\hline H98 & $\begin{array}{l}\mathrm{HL} \\
\mathrm{EL} \\
\mathrm{JL}\end{array}$ & $\begin{array}{c}5 \\
0 \mathrm{NS} \\
24 *\end{array}$ & $\begin{array}{c}9 \\
5 \mathrm{NS} \\
37 * * *\end{array}$ & $\begin{array}{c}18 \\
21 \mathrm{NS} \\
31 \mathrm{NS}\end{array}$ & $\begin{array}{c}73 \\
81 \mathrm{NS} \\
31 * * *\end{array}$ & $\begin{array}{c}-12 \\
-22 * * * \\
+1 * * *\end{array}$ \\
\hline $\mathrm{S}$ & $\begin{array}{l}\text { HL } \\
\text { EL }\end{array}$ & $\begin{array}{c}0 \\
1 \mathrm{NS}\end{array}$ & $\begin{array}{c}5 \\
6 \mathrm{NS}\end{array}$ & $\begin{array}{c}1 \\
49^{\mathrm{e}}\end{array}$ & $\begin{array}{c}42 \\
88 * * *\end{array}$ & $\begin{array}{c}-15 \\
-18 \mathrm{NS}\end{array}$ \\
\hline NT & $\begin{array}{c}\mathrm{HL} \\
\mathrm{JL}\end{array}$ & $\begin{array}{c}12 \\
5 \mathrm{NS}\end{array}$ & $\begin{array}{c}50 \\
57 \mathrm{NS} \\
\end{array}$ & $\begin{array}{c}30 \\
31 \mathrm{NS}\end{array}$ & $\begin{array}{c}73 \\
38 *\end{array}$ & $\begin{array}{c}-4 \\
+11 \mathrm{NS} \\
\end{array}$ \\
\hline
\end{tabular}

${ }^{a}$ EL, JL, HL denote European larch, Japanese larch and hybrid larch, respectively

${ }^{\mathrm{b}}$ Values rounded to the nearest unit

${ }^{\mathrm{c}}$ Growth reduction $\%=($ length of terminal shoot in 2008 - mean length of terminal shoot in 2006 and 2007) * $100 /$ mean length of terminal shoot in 2006 and 2007

$\mathrm{d} *, * *, * * *$ denote that European larch or Japanese larch trees differed significantly from the hybrids at $\mathrm{P}=0.05, \mathrm{P}=0.01$ and $\mathrm{P}=0.001$, respectively ( $\mathrm{NS}=$ non-significant)

${ }^{\mathrm{e}}$ The mean comparison test was not applicable due to too few damaged HL trees 
Table 4 Hybrid performance (expressed in \% relative to European larch (EL) and Japanese larch (JL)) for the orchard progenies tested at Peyrat,

Brenod and La Courtine. The studied characters are represented by their initials followed by the age since planting. $\mathrm{H}$ is total height, $\mathrm{C}$ is circumference, $\mathrm{V}$ is volume, HD is height:diameter ratio, SS is stem straightness and MOE is modulus of elasticity.

\begin{tabular}{|c|c|c|c|c|c|c|c|c|c|c|c|c|c|}
\hline \multirow[t]{2}{*}{ Site } & \multirow{2}{*}{$\begin{array}{l}\text { Orchard } \\
\text { progeny }\end{array}$} & \multicolumn{2}{|c|}{ H7 } & \multicolumn{2}{|c|}{ C10 } & \multicolumn{2}{|c|}{ V7 } & \multicolumn{2}{|c|}{ HD7 } & \multicolumn{2}{|c|}{ SS10 } & \multicolumn{2}{|c|}{ MOE 12} \\
\hline & & EL & $\mathbf{J L}$ & EL & $\mathbf{J L}$ & EL & $\mathbf{J L}$ & EL & $\mathbf{J L}$ & $\mathbf{E L}$ & $\mathbf{J L}$ & EL & $\mathbf{J L}$ \\
\hline \multirow{8}{*}{ Peyrat } & \multirow{6}{*}{$\begin{array}{l}\text { FH } \\
\text { H87 } \\
\text { H98 } \\
\text { NT } \\
\text { S } \\
\text { V }\end{array}$} & $43 * * *$ & & $73 * * *$ & & $185^{* * * *}$ & & $-16 * * *$ & & $-4 \mathrm{NS}$ & & $-39 * * *$ & \\
\hline & & $21 * * *$ & $7 *$ & $53 * * *$ & $4 \mathrm{NS}$ & $145^{* * * *}$ & $41 \mathrm{NS}$ & $-20 * * *$ & $7 *$ & $-7 \mathrm{NS}$ & $3 \mathrm{NS}$ & $-16 \mathrm{NS}$ & $0 \mathrm{NS}$ \\
\hline & & $9 * *$ & $16^{* * *}$ & $23 * * *$ & $10 \mathrm{NS}$ & $53 * * *$ & $43 * *$ & $-14 * * *$ & $-2 \mathrm{NS}$ & $-8 \mathrm{NS}$ & $5 \mathrm{NS}$ & $-13 \mathrm{NS}$ & $16 \mathrm{NS}$ \\
\hline & & & $-5 \mathrm{NS}$ & & $-7 \mathrm{NS}$ & & $-14 \mathrm{NS}$ & & $20 \mathrm{NS}$ & & $10 \mathrm{NS}$ & & $49 * *$ \\
\hline & & $22 * * *$ & & $54 * * *$ & & $193^{* * * *}$ & & $-22 * * *$ & & $-3 N S$ & & $3 \mathrm{NS}$ & \\
\hline & & $32 * * *$ & & $81 * * *$ & & $275^{* * * *}$ & & $-25 * * *$ & & $-1 \mathrm{NS}$ & & $-40 * * *$ & \\
\hline & & \multicolumn{2}{|c|}{ H6 } & \multicolumn{2}{|c|}{$\mathrm{C13}$} & \multicolumn{2}{|c|}{ V6 } & \multicolumn{2}{|c|}{ HD6 } & \multicolumn{2}{|c|}{ SS6 } & & \\
\hline & & $\mathbf{E L}$ & JL & $\mathbf{E L}$ & $\mathbf{J L}$ & EL & $\mathbf{J L}$ & $\mathbf{E L}$ & JL & EL & JL & & \\
\hline \multirow{9}{*}{ Brenod } & FH & $27 * * *$ & & $51 * * *$ & & $161^{* * *}$ & & $-12 * *$ & & $-15 * *$ & & & \\
\hline & H80 & & $5 \mathrm{NS}$ & & $\mathrm{b}$ & & $29(*)$ & & $-1 \mathrm{NS}$ & & $3 \mathrm{NS}$ & & \\
\hline & $\mathbf{H 8 3}$ & & $14 * * *$ & & $14 * * *$ & & $79 * * *$ & & $-9(*)$ & & $9 \mathrm{NS}$ & & \\
\hline & $\mathbf{V}$ & $17 *$ & & $50 * * *$ & & $122 *$ & & $-13(*)$ & & $-17 \mathrm{NS}$ & & & \\
\hline & $\mathbf{E}$ & $\mathrm{a}$ & & $\mathrm{a}$ & & $\mathrm{a}$ & & $\mathrm{a}$ & & $\mathrm{a}$ & & & \\
\hline & $\mathbf{M}$ & & $30 * * *$ & & $33 * * *$ & & $178 * * *$ & & $-20 * * *$ & & $-13 *$ & & \\
\hline & FP & $70 * * *$ & & $99 * * *$ & & $658 * * *$ & & $-33 * * *$ & & $-8^{*}$ & & & \\
\hline & & \multicolumn{2}{|c|}{ H6 } & \multicolumn{2}{|c|}{$\mathrm{C10}$} & \multicolumn{2}{|c|}{ V6 } & \multicolumn{2}{|c|}{ HD6 } & \multicolumn{2}{|c|}{ SS6 } & & \\
\hline & & $\mathbf{E L}$ & JL & $\mathbf{E L}$ & $\mathbf{J L}$ & EL & $\mathbf{J L}$ & EL & JL & $\mathbf{E L}$ & JL & & \\
\hline \multirow{4}{*}{$\begin{array}{l}\text { La } \\
\text { Courtine }\end{array}$} & FH & $27 * * *$ & & $57 * * *$ & & $132 * * *$ & & $-6 \mathrm{NS}$ & & $-4 \mathrm{NS}$ & & & \\
\hline & H83 & & $10^{* *}$ & & $8(*)$ & & $33^{* *}$ & & $-4 \mathrm{NS}$ & & $8 \mathrm{NS}$ & & \\
\hline & $\mathbf{E}$ & $30 * * *$ & & $72 * * *$ & & $185^{* * * *}$ & & $-16 * * *$ & & $-2 N S$ & & & \\
\hline & $\mathbf{M}$ & & 7* & & $5 \mathrm{NS}$ & & $27 *$ & & 9* & & $-3 \mathrm{NS}$ & & \\
\hline
\end{tabular}


Author-produced version of the article published in New Forests, 2016, 47 (4), 541-564.

The original publication is available at http://link.springer.com/article/10.1007/s11056-016-9530-z doi: $10.1007 / \mathrm{s} 11056-016-9530-z$

$(*), *, * * * *$ denote a significant effect of species at $\mathrm{P}=0.10, \mathrm{P}=0.05, \mathrm{P}=0.01$ and $\mathrm{P}=0.001$, respectively $(\mathrm{NS}=$ non-significant)

${ }^{a}$ The analysis would be meaningless because of two few European larch trees in the orchard progeny

${ }^{\mathrm{b}}$ The orchard progeny was not measured 
Table 5 Variability (coefficients of variation) of populations composed of all trees (all) or hybrid trees only (HL) for the seed orchard progenies tested at Peyrat, Brenod and La Courtine. The studied characters are represented by their initials followed by the age since planting. $\mathrm{H}$ is total height, $\mathrm{C}$ is circumference, $\mathrm{V}$ is volume, HD is height:diameter ratio and SS is stem straightness.

\begin{tabular}{|c|c|c|c|c|c|c|c|c|c|c|c|}
\hline \multirow[t]{2}{*}{ Site } & \multirow{2}{*}{$\begin{array}{l}\text { Orchard } \\
\text { progeny }\end{array}$} & \multicolumn{2}{|c|}{ H7 } & \multicolumn{2}{|c|}{ C10 } & \multicolumn{2}{|c|}{ V7 } & \multicolumn{2}{|c|}{ HD7 } & \multicolumn{2}{|c|}{ SS10 } \\
\hline & & all & HL & all & HL & all & HL & all & HL & all & HL \\
\hline \multirow[t]{8}{*}{ Peyrat } & \multirow{6}{*}{$\begin{array}{l}\text { FH } \\
\text { H87 } \\
\text { H98 } \\
\text { NT } \\
\text { S } \\
\text { V } \\
\end{array}$} & 17.5 & 10.0 & 23.4 & 12.2 & 47.8 & 31.7 & 13.9 & 12.0 & 17.2 & 17.7 \\
\hline & & 16.1 & 15.1 & 25.6 & 21.7 & 55.2 & 45.0 & 18.5 & 15.5 & 20.6 & 19.8 \\
\hline & & 14.8 & 11.6 & 23.2 & 21.2 & 52.7 & 42.9 & 17.1 & 15.2 & 26.5 & 27.5 \\
\hline & & 17.9 & 25.2 & 20.0 & 28.3 & 54.0 & 75.1 & 31.8 & 52.5 & 24.7 & 18.8 \\
\hline & & 18.8 & 13.9 & 31.4 & 20.0 & 84.3 & 53.2 & 15.5 & 13.0 & 17.2 & 24.5 \\
\hline & & 15.0 & 10.2 & 25.6 & 15.5 & 48.2 & 32.1 & 18.7 & 12.9 & 19.7 & 20.5 \\
\hline & & \multicolumn{2}{|c|}{ H6 } & \multicolumn{2}{|c|}{ C13 } & \multicolumn{2}{|c|}{ V6 } & \multicolumn{2}{|c|}{ HD6 } & \multicolumn{2}{|c|}{ SS6 } \\
\hline & & all & HL & all & HL & all & HL & all & HL & all & HL \\
\hline \multirow[t]{9}{*}{ Brenod } & FH & 18.3 & 14.2 & 22.3 & 17.3 & 58.3 & 46.8 & 23.3 & 22.5 & 28.0 & 28.5 \\
\hline & H80 & 15.1 & 18.2 & $\mathrm{a}$ & $\mathrm{a}$ & 60.1 & 71.9 & 15.8 & 17.3 & 33.5 & 33.7 \\
\hline & H83 & 16.4 & 14.5 & 13.8 & 12.1 & 62.5 & 61.6 & 19.3 & 13.2 & 32.9 & 29.9 \\
\hline & $\mathbf{V}$ & 19.3 & 18.8 & 21.7 & 19.4 & 66.2 & 61.9 & 21.6 & 20.9 & 34.8 & 36.5 \\
\hline & $\mathbf{E}$ & 16.6 & 16.2 & 16.3 & 16.2 & 49.8 & 47.5 & 20.0 & 18.0 & 23.7 & 24.3 \\
\hline & M & 24.3 & 20.2 & 24.1 & 17.6 & 99.6 & 71.7 & 27.5 & 18.5 & 30.7 & 36.8 \\
\hline & FP & 41.0 & 25.1 & 46.5 & 22.7 & 201.2 & 100.7 & 36.3 & 22.5 & 16.2 & 15.8 \\
\hline & & \multicolumn{2}{|c|}{ H6 } & \multicolumn{2}{|c|}{ C10 } & \multicolumn{2}{|c|}{ V6 } & \multicolumn{2}{|c|}{ HD6 } & \multicolumn{2}{|c|}{ SS6 } \\
\hline & & all & HL & all & HL & all & HL & all & HL & all & HL \\
\hline \multirow[t]{4}{*}{ Courtine } & FH & 16.1 & 12.4 & 23.4 & 18.1 & 48.6 & 40.6 & 15.5 & 16.4 & 25.5 & 26.1 \\
\hline & H83 & 13.9 & 10.7 & 15.0 & 18.3 & 43.9 & 39.2 & 15.2 & 12.7 & 33.2 & 34.3 \\
\hline & $\mathbf{E}$ & 13.2 & 9.1 & 21.1 & 15.2 & 41.8 & 32.7 & 16.9 & 15.6 & 24.1 & 24.8 \\
\hline & $\mathbf{M}$ & 18.4 & 21.5 & 20.5 & 23.0 & 56.7 & 61.0 & 20.1 & 25.9 & 30.3 & 32.4 \\
\hline
\end{tabular}


Author-produced version of the article published in New Forests, 2016, 47 (4), 541-564.

The original publication is available at http://link.springer.com/article/10.1007/s11056-016-9530-z

${ }^{a}$ The orchard progeny was not measured 
2 Table 6 Measures that can be taken by tree breeders, seed orchard managers, seed plant

3 managers and nurserymen to increase hybrid percentage in Forest Reproductive Materials

4 (FRM) produced in F1-hybridization seed orchards (options including vegetative propagation

5 are voluntarily excluded)

\begin{tabular}{|c|c|c|}
\hline Stage & $\begin{array}{l}\text { Orchard composed of } \mathrm{EL}^{\mathrm{a}} \text { and } \mathrm{JL}^{\mathrm{a}} \\
\text { clones }\end{array}$ & Separate orchards of $\mathrm{EL}^{\mathrm{a}}$ and $\mathrm{JL}^{\mathrm{a}}$ \\
\hline \multirow[t]{2}{*}{$\begin{array}{l}\text { Genotype } \\
\text { selection }\end{array}$} & $\begin{array}{l}\text { Use a single mother clone } \\
\text { "phenologically" compatible with } \\
\text { the clone(s) used as pollen } \\
\text { producer(s) }{ }^{\text {b. }}\end{array}$ & $\begin{array}{l}\text { Use a single mother clone selected for } \\
\text { its performance, irrespective of } \\
\text { phenology. }\end{array}$ \\
\hline & \multicolumn{2}{|c|}{$\begin{array}{l}\text { Verify the identity (EL or JL) of the parent clones with molecular markers } \\
\text { (Acheré et al. 2004). }\end{array}$} \\
\hline \multirow{2}{*}{$\begin{array}{l}\text { Orchard } \\
\text { establishment }\end{array}$} & \multicolumn{2}{|c|}{ Verify that the site is well-isolated from incoming pollen. } \\
\hline & $\begin{array}{l}\text { Prefer tree by tree alternation of } \\
\text { species. }\end{array}$ & $\begin{array}{l}\text { Consider establishing indoor-orchards } \\
\text { in northern countries (Colas } \text { et al. } \\
\text { 2008) and take measures to reduce } \\
\text { epigenetic effects. }\end{array}$ \\
\hline $\begin{array}{l}\text { Orchard } \\
\text { management }\end{array}$ & \multicolumn{2}{|c|}{$\begin{array}{l}\text { Control for and eradicate rootstock suckers (“graft rejection”). } \\
\text { Preferably use the alternate species rootstock. }\end{array}$} \\
\hline $\begin{array}{l}\text { Flower } \\
\text { management }\end{array}$ & $\begin{array}{l}\text { Flower stimulation and SMP } \text { SMe }^{\mathrm{c}} \text { are } \\
\text { highly recommended (Philippe et } \\
\text { al. 2006, Pâques et al. 2013). } \\
\text { Monitor flower development to } \\
\text { estimate the flowering overlap } \\
\text { between EL and JL clones (and } \\
\text { possible pollen contamination). }\end{array}$ & $\begin{array}{l}\text { Flower stimulation is highly } \\
\text { recommended. } \\
\text { SMP }^{\mathrm{c}} \text { is mandatory. } \\
\text { Monitor flower development to make } \\
\text { decisions for pollen collection (pollen } \\
\text { cone maturation) and } \mathrm{SMP}^{\mathrm{c}} \text { (seed cone } \\
\text { receptivity). }\end{array}$ \\
\hline \multirow[b]{2}{*}{$\begin{array}{l}\text { Cone } \\
\text { collection }\end{array}$} & \multicolumn{2}{|c|}{$\begin{array}{l}\text { Estimate hybrid seed \% in advance with molecular markers (possible as } \\
\text { early as August) and collect cones or not according to the result. }\end{array}$} \\
\hline & $\begin{array}{l}\text { Avoid collecting cones in case of } \\
\text { poor flowering, poor flowering } \\
\text { overlap between EL and JL or } \\
\text { pollen contamination. }\end{array}$ & \\
\hline \multirow[t]{2}{*}{$\begin{array}{l}\text { Cone and seed } \\
\text { processing }\end{array}$} & $\begin{array}{l}\text { If the cones are collected from } \\
\text { both species, treat EL and JL } \\
\text { progenies separately in the seed } \\
\text { plant. }\end{array}$ & \\
\hline & \multicolumn{2}{|c|}{$\begin{array}{l}\text { Determine hybrid seed \% after seed processing and do not market seed lots } \\
\text { with low hybrid percentage. }\end{array}$} \\
\hline $\begin{array}{l}\text { Raising } \\
\text { seedlings }\end{array}$ & \multicolumn{2}{|c|}{$\begin{array}{l}\text { Use molecular markers or phenotypic tests to sort out the seedlings in the } \\
\text { nursery (Acheré et al. 2004, Pâques et al. 2006). }\end{array}$} \\
\hline
\end{tabular}


$1{ }^{b}$ The products of orchards with a single mother clone have a low genetic diversity. Thus, it is 2 recommended to vary the FRM used at a regional scale to reduce sanitary risks. In addition, 3 the plantations deriving from such orchards must not be regenerated naturally.

$5 \quad{ }^{\mathrm{c}}$ SMP: supplemental mass pollination 
2 Fig. 1 (xls) Effect of simulated first thinnings on hybrid percentage for the seed orchard

3 progenies tested at Peyrat. The thinnings were based on either tree volume at age 10 (V10),

4 stem straightness at age 10 (SS10) or an index combining both traits (index V10 + SS10).

5 Simulations were made considering that thinning would eliminate $30 \%$ of the living trees.

6

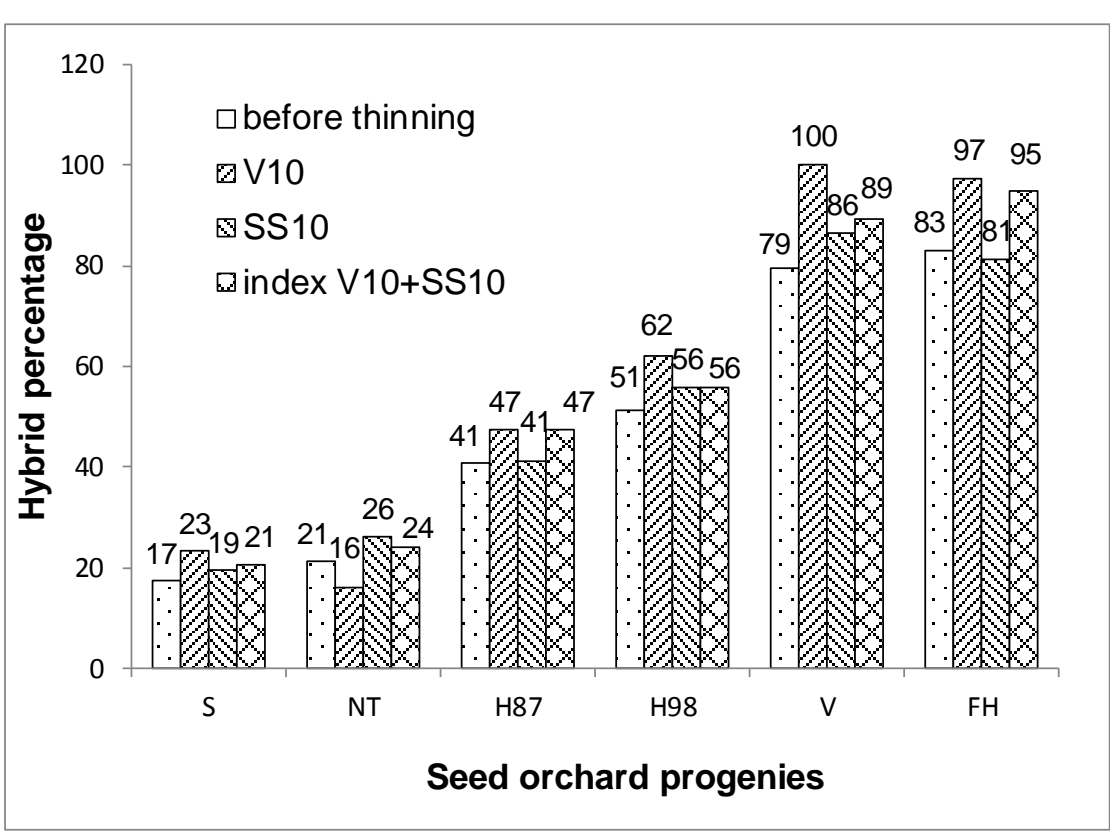


2 Fig. 2 (xls) Effect of simulated and actual first thinnings on hybrid percentage for the seed

3 orchard progenies tested at Brenod and La Courtine. The thinning simulations were based on

4 either circumference or stem straightness (measured at age 13 for Brenod and 10 for La

5 Courtine). Simulations were made considering that thinning would eliminate $50 \%$ of the

6 living trees. Thinning could not be simulated for $\mathrm{H} 80$ at Brenod because this orchard progeny

7 had not been measured. Actual thinnings, carried out at age 14 at Brenod and age 11 at La

8 Courtine, were partly systematic and partly selective (criteria: vigor, stem form and spatial

9 distribution of the trees); they eliminated $45 \%$ and $42 \%$ of the living trees at Brenod and La

10 Courtine, respectively.

11

12

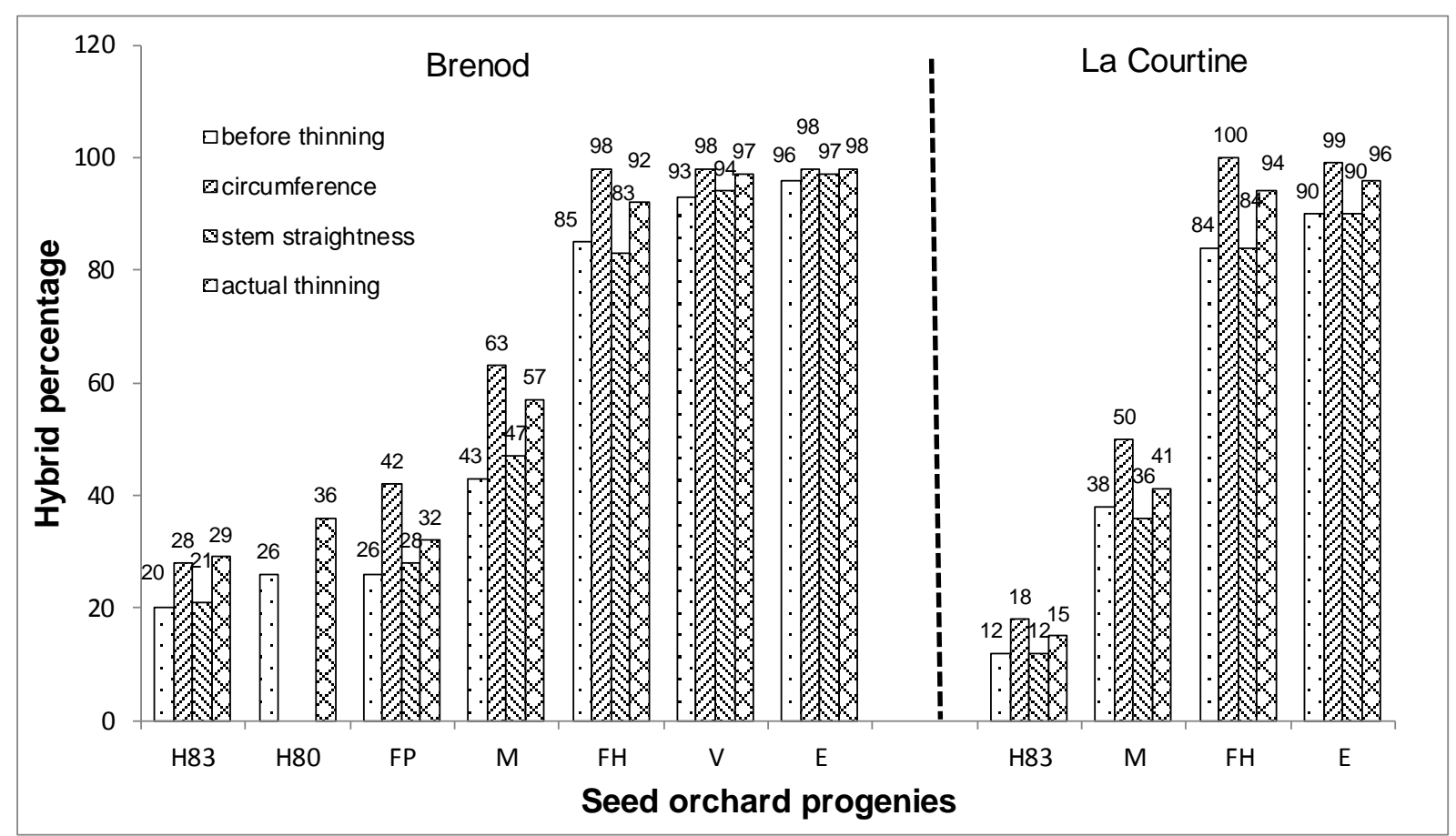

13

14 
2 Fig. 3 (xls) Effect of simulated second and third thinnings on hybrid percentage for the seed

3 orchard progenies tested at Brenod and La Courtine. Thinning simulations were based on

4 either circumference (C) or stem straightness (SS) measured after actual first thinning (at age

517 for Brenod and 16 for La Courtine). Simulations were made considering that tree density

6 would be reduced from 790 trees/ha or 940 trees/ha (density after actual first thinning at

7 Brenod and La Courtine, respectively) to 600 trees/ha after the second thinning and then to

8400 trees/ha after the third thinning. For each orchard progeny, the figure can be read from the

9 black central bar which represents the hybrid percentage after actual first thinning. The two

10 bars on its left indicate the corresponding percentage after $2^{\text {nd }}$ and $3^{\text {rd }}$ thinnings based on stem

11 straightness; the two bars on its right indicate hybrid percentage after $2^{\text {nd }}$ and $3^{\text {rd }}$ thinnings

12 based on tree circumference.

13

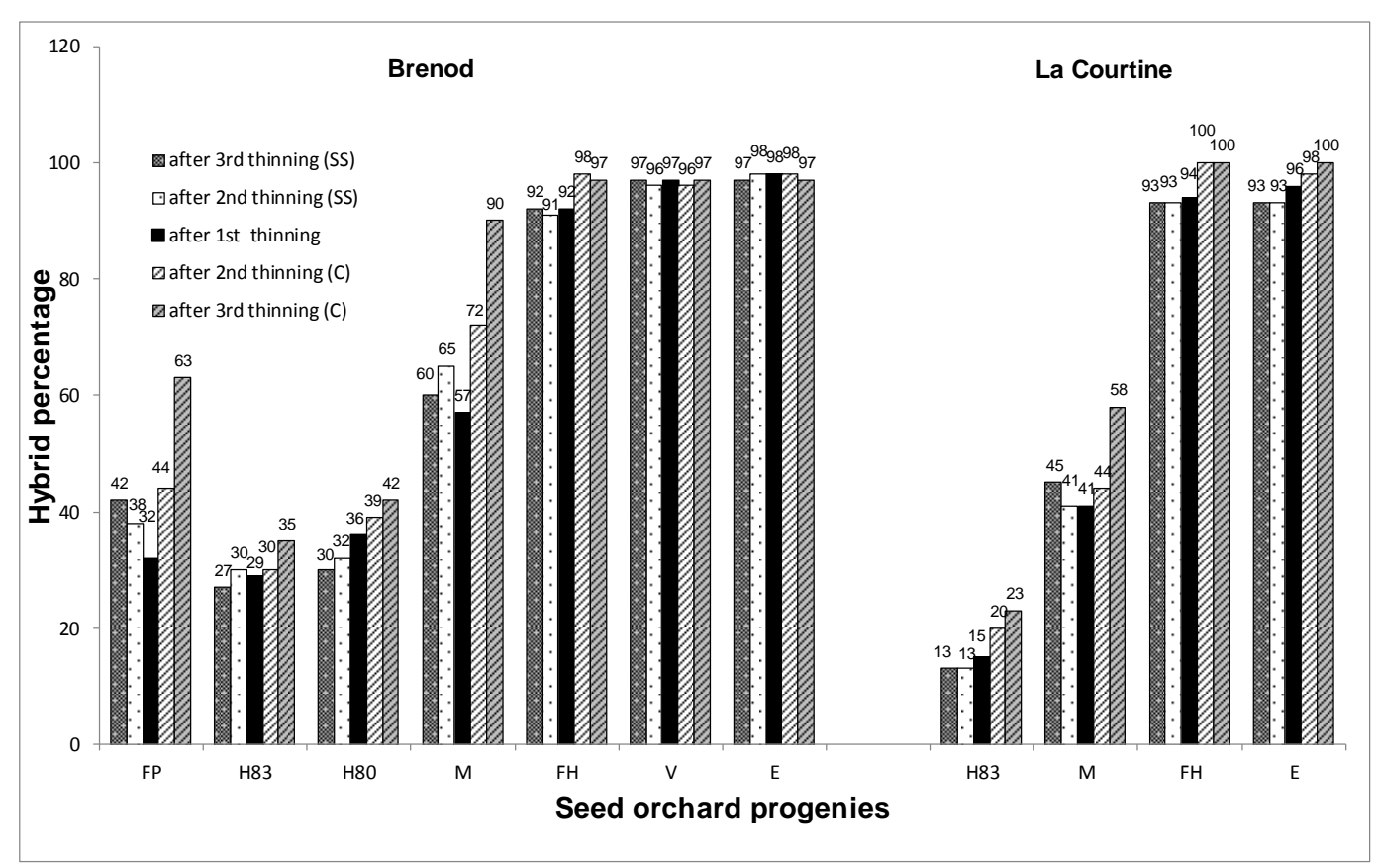

15

16 
2 Fig. 4 (xls) Ranking of the seed orchard progenies tested at La Courtine and Brenod for tree

3 volume at age 6, considering populations composed of all trees or hybrid trees only. For each

4 site, orchard progenies with the same letter were not significantly different $(\mathrm{P}=0.05)$. The

5 homogeneous groups found for all trees and hybrid trees are represented by letters of normal

6 type and letters in bold, respectively.

7

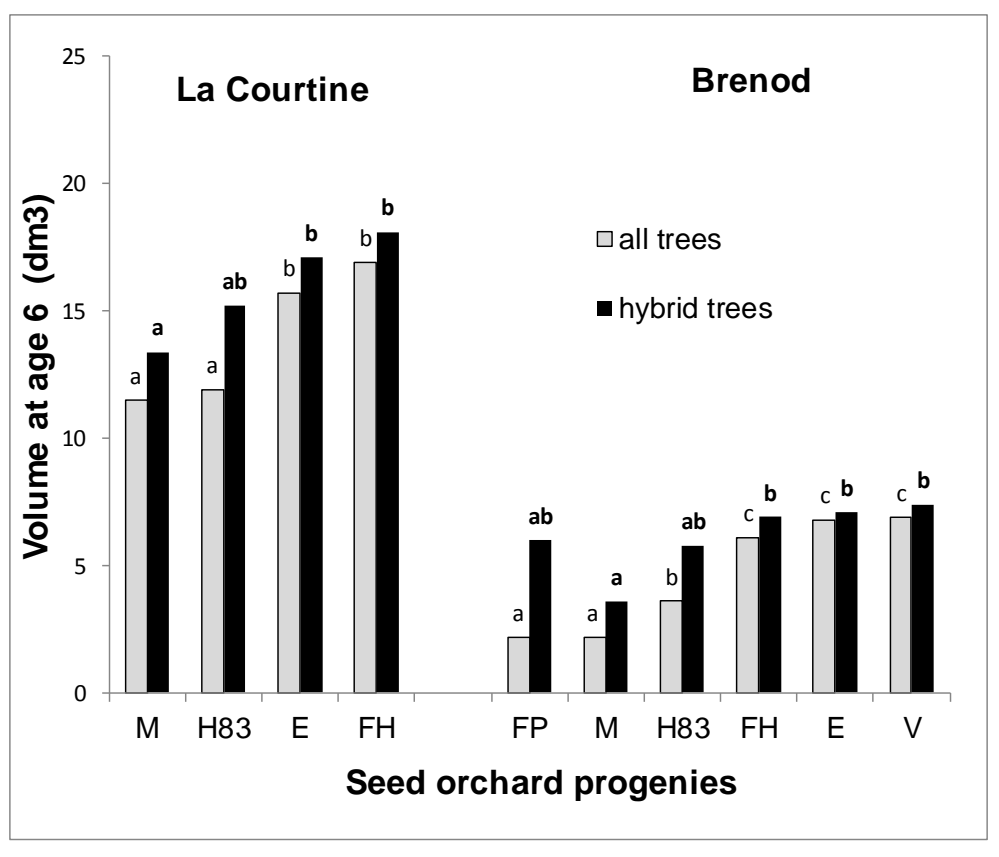

8

10

11 
2 Fig. 5 (xls) Ranking of the seed orchard progenies tested at Brenod for circumference at age 6

3 (C6) and girth increment between ages 6 and 13 (C6-13), considering populations composed

4 of all trees or hybrid trees only. For each population, orchard progenies with the same letter

5 were not significantly different $(\mathrm{P}=0.05)$. The homogeneous groups found for circumference

6 at age 6 and girth increment are represented by letters in the middle of the corresponding bar;

7 those found for circumference at age 13 are represented by letters in bold above the two bars.

8

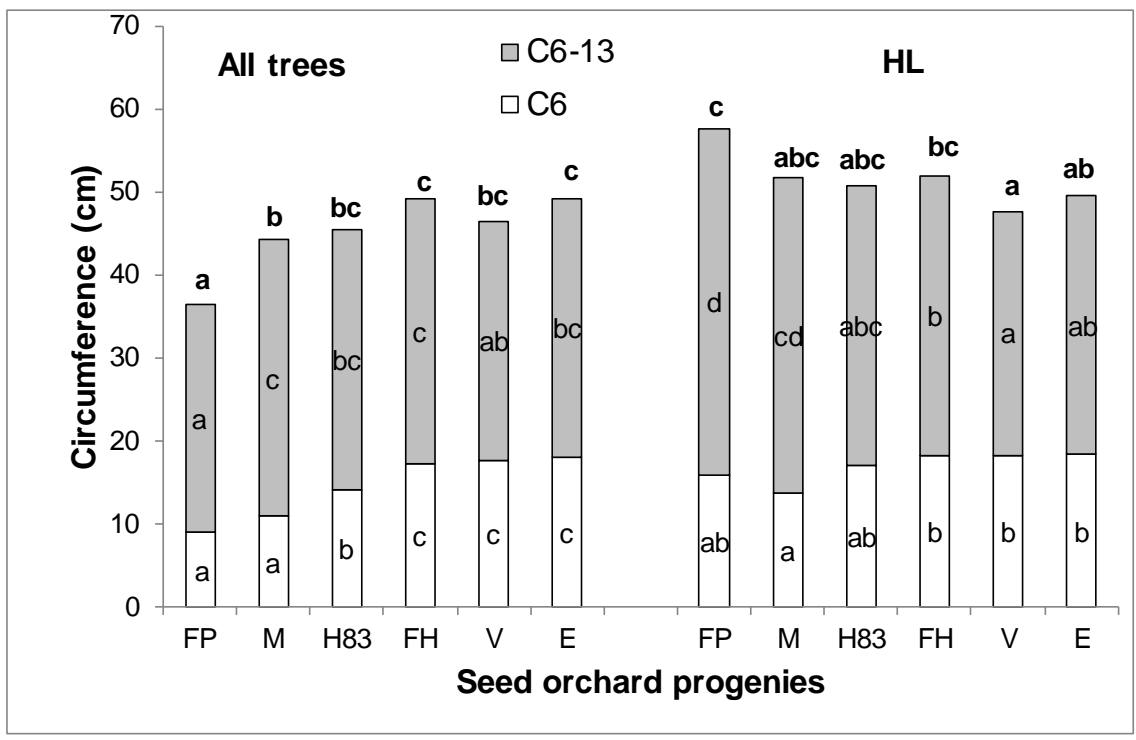

10 